Article

\title{
Fine-Resolution Repeat Topographic Surveying of Dryland Landscapes Using UAS-Based Structure-from-Motion Photogrammetry: Assessing Accuracy and Precision against Traditional Ground-Based Erosion Measurements
}

\author{
Jeffrey K. Gillan ${ }^{1, *}$, Jason W. Karl ${ }^{1}$, Ahmed Elaksher ${ }^{2}$ and Michael C. Duniway ${ }^{3}$ \\ 1 US Department of Agriculture-Agricultural Research Service, Jornada Experimental Range, \\ New Mexico State University, Las Cruces, NM 88001, USA; jason.karl@ars.usda.gov \\ 2 Civil Engineering Department, College of Engineering, California Polytechnical State University, Pomona, \\ CA 91766, USA; afelaksher@cpp.edu \\ 3 US Geological Survey, Southwest Biological Science Center, Moab, UT 84532, USA; mduniway@usgs.gov \\ * Correspondence: jgillan@nmsu.edu; Tel.: +1-530-339-5975
}

Academic Editors: Ioannis Gitas, Magaly Koch and Prasad S. Thenkabail Received: 10 March 2017; Accepted: 21 April 2017; Published: 3 May 2017

\begin{abstract}
Structure-from-motion (SfM) photogrammetry from unmanned aerial system (UAS) imagery is an emerging tool for repeat topographic surveying of dryland erosion. These methods are particularly appealing due to the ability to cover large landscapes compared to field methods and at reduced costs and finer spatial resolution compared to airborne laser scanning. Accuracy and precision of high-resolution digital terrain models (DTMs) derived from UAS imagery have been explored in many studies, typically by comparing image coordinates to surveyed check points or LiDAR datasets. In addition to traditional check points, this study compared $5 \mathrm{~cm}$ resolution DTMs derived from fixed-wing UAS imagery with a traditional ground-based method of measuring soil surface change called erosion bridges. We assessed accuracy by comparing the elevation values between DTMs and erosion bridges along thirty topographic transects each $6.1 \mathrm{~m}$ long. Comparisons occurred at two points in time (June 2014, February 2015) which enabled us to assess vertical accuracy with 3314 data points and vertical precision (i.e., repeatability) with 1657 data points. We found strong vertical agreement (accuracy) between the methods (RMSE 2.9 and $3.2 \mathrm{~cm}$ in June 2014 and February 2015, respectively) and high vertical precision for the DTMs (RMSE $2.8 \mathrm{~cm}$ ). Our results from comparing SfM-generated DTMs to check points, and strong agreement with erosion bridge measurements suggests repeat UAS imagery and SfM processing could replace erosion bridges for a more synoptic landscape assessment of shifting soil surfaces for some studies. However, while collecting the UAS imagery and generating the SfM DTMs for this study was faster than collecting erosion bridge measurements, technical challenges related to the need for ground control networks and image processing requirements must be addressed before this technique could be applied effectively to large landscapes.
\end{abstract}

Keywords: dryland erosion; photogrammetry; road network disturbance; UAS; erosion bridge

\section{Introduction}

Repeat topographic surveys are an important tool for studying and managing dryland ecosystems, particularly for tracking soil erosion and gully formation [1-5]. Other applications include hydrologic erosion modeling [6,7], formulating ecohydrologic models [8], predicting plant species occurrence via 
topographic attributes [9], and delineating watersheds at a very fine scale to improve studies of water and energy cycling in water-limited ecosystems [10].

An emerging tool for repeat topographic surveying is structure-from-motion (SfM) photogrammetry derived from unmanned aerial system (UAS) imagery [4,11-14]. Use of this tool has increased dramatically due to the proliferation of low-cost and easily accessible consumer UAS, the availability of many off-the-shelf sensors small enough to be carried aboard small aircraft [15], and advances in computer vision and software to process imagery [16,17]. SfM differs from traditional photogrammetry in that it can reconstruct 3-dimensional scenes based purely on a large number (typically millions) of automatically detected ground points in many overlapping images independent of ground references [18]. This allows it to be very flexible in terms of accepting images with inconsistent overlap, rotation between successive images, and images from different angles (i.e., nadir and oblique) [19]. SfM can also handle images collected with consumer grade cameras with unknown or unstable lens characteristics [20]. Traditional photogrammetry is less flexible in that it requires consistent image overlap, minimal rotation between successive images, and calibrated sensors [19]. The flexibility of SfM is ideal for UAS-based topography surveying. Scientists and land managers now have the ability to make on-demand imagery products, often at finer spatial and temporal resolutions along with reduced costs compared to imagery from satellite or manned aircraft [21].

A typical product of image-based reconstructions are digital terrain models (DTMs; i.e., bare ground). Differencing a time-series of DTMs constructed from UAS imagery enables quantification and visualization of soil movement (i.e., erosion and deposition) in more detail and over a larger area compared to field methods such as erosion bridges [22], erosion pins [23,24], and total station surveying [25,26]. Additionally, high-resolution SfM DTMs can be produced at a finer resolution and lower cost compared to airborne laser scanning [27] and can cover a larger geographic extent but with a reduction in detail compared with terrestrial laser scanning [28].

Knowing the expected accuracy (i.e., correctly representing the terrain) and precision (i.e., repeatability of terrain measurements) are critical aspects of using this tool effectively for repeat topographic surveys. Past research has shown that high-resolution $(<10 \mathrm{~cm}$ ground sampling distance) DTMs from UAS can be created with vertical accuracy $<5 \mathrm{~cm}[3,17,29-32]$. Quantifying vertical repeatability is essential to separate model error from actual surface change [26,33]. Past studies of high-resolution DTMs have found repeatability to be on average $1.7-6 \mathrm{~cm}[13,30]$.

Many research papers have reported accuracy and precision of SfM DTMs by using surveyed check points or comparison with LiDAR derived DTMs. None, however, have directly compared the results with concurrent erosion bridges, a common field method that has been demonstrated to effectively measure small topography changes for many natural resource applications including livestock impacts [34], post-fire erosion [35-38], erosion rates in cultivated fields [39], and impacts of recreational trails [40]. Though they can detect micro changes in soil surface with high precision, erosion bridges measure linear topographic profiles usually at lengths between 1 and $10 \mathrm{~m}$, making it possible only to sample small portions of the landscape. Additionally, the choice of where to locate erosion bridges in a study area requires a priori knowledge and anticipation of where soil movement will occur. Unexpected consequences of the disturbance or process of interest may cause soil erosion to occur in places not sampled by the erosion bridges. Alternatively, measuring soil surface change via UAS photography and SfM methods provides synoptic observation of entire study areas and the ability to spatially locate sources and sinks of sediment movement, including areas with unexpected results.

In this paper, we directly compare SfM DTMs with erosion bridge data to demonstrate that the method of UAS-based SfM DTMs, though more technically challenging, can provide additional benefits of increasing sampling area. Included are analyses showing the differences in accuracy and precision that can be expected between the field and aerial methods. We demonstrate these methods in the context of investigating erosional impacts of unpaved road networks across the landscape. 
The proliferation of unpaved road networks on public lands is a persistent and pressing problem for land managers globally [41], particularly in the western USA [42,43]. These unpaved roads present a challenge for soil conservation [44], with assessments of road erosion often relying on modelling that is not well parameterized to highly disturbed conditions [45,46]. Many immediate and pronounced impacts from roads and related disturbances are associated with altered erosion and hydrology $[47,48]$ which are not well captured by common rangeland monitoring methods (e.g., Herrick et al. [49]). The USDA-Agricultural Research Service Jornada Experimental Range (JER) is conducting a long-term controlled experiment called Threshold Resistance and Connectivity (TRAC) to investigate further the effect of road networks on rangeland health. Across an 870 ha watershed, a series of unpaved roads were constructed with a road grader and received vehicle driving treatments several times per year which consisted of driving on the roads with a $4 \mathrm{WD}$ pick-up truck to simulate traffic. The soil erosion and compaction component of the TRAC study is currently being measured with a series of erosion bridges which sample a small portion of the experimental roads. A UAS-based DTM differencing approach to measuring soil erosion from roads could greatly expand and improve data collection for this study, as well as provide an important tool for land managers tasked with monitoring conditions on unpaved road networks. Though we test this technology over a relatively small area (15 ha), we view the results in terms of expanding the geographic extent and discuss the opportunities and challenges of scaling-up this approach.

The objectives of this project were to: (1) create high-resolution SfM DTMs from UAS-acquired imagery and assess their accuracy by comparing surface elevation profiles from the DTM with in situ close-range laser measurements from erosion bridges; (2) assess precision (i.e., repeatability) of SfM DTMs between image acquisition dates in order to quantify the level of topographic change that is detectable; (3) conduct DTM differencing to quantify and visualize soil movement over a 9 month time-span; and (4) assess the feasibility of applying these methods to large landscapes ( $>200 \mathrm{ha}$ ).

\section{Materials and Methods}

\subsection{Study Area}

We conducted this study at the JER north of Las Cruces, NM $\left(32^{\circ} 36^{\prime} 19.30^{\prime \prime} \mathrm{N}, 106^{\circ} 37^{\prime} 12.14^{\prime \prime} \mathrm{W}\right.$; $1420 \mathrm{~m}$ ). The JER lies on the northern end of the Chihuahuan Desert and has a semi-arid climate. The study area received $293 \mathrm{~mm}$ of precipitation during the study period from June 2014 to February 2015 with more than half of the precipitation falling as the late summer monsoon rains. The TRAC study is located on a broad alluvial fan emanating from the western flank of the San Andres Mountains. The study area slopes gently from east to west with an average of slope of $2^{\circ}$. The soil was characterized as shallow gravelly loam (Ecological Site ID R042XB010NM). Shrubs dominated by Larrea tridentata (Creosote), Prosopis glandulosa (Mesquite), Flourensia cernua (Tarbush), and Parthenium incanum (Mariola) cover approximately $40-50 \%$ of the study, while an understory of grasses and forbs is nearly non-existent.

The TRAC project has a total of 47 plots $(50 \times 50 \mathrm{~m})$ spread out over 870 ha (Figure 1$)$. We selected a subset of six test plots within a 15 ha strip to compare UAS-based topographic surveying with erosion bridge measurements. The layout of the plots was chosen to be along a north-south line, which facilitated image acquisition.

\subsection{Field Measurements}

As part of the TRAC project, soil surface elevation profiles were measured in June 2014 and February 2015 along 5 linear transects in each plot using a laser range finder mounted on an erosion bridge (Figures 2 and 3). The erosion bridge consisted of a metal beam suspended approximately $1.5 \mathrm{~m}$ above the ground using tripods on each side for support. Permanent nails in the ground marked the beginning and end of each transect and also provided a guide to set up the bridge identically each time. A laser range finder (Leica Disto D8) was slid along the beam in a rolling carriage and the distance 
from the beam to the ground was recorded every $10 \mathrm{~cm}$ along the $6.1 \mathrm{~m}$ erosion bridge for a total of 62 measurements. The laser had footprint of $\sim 0.1 \mathrm{~mm}$. Adjustments were made to account for slight sag in the middle of the beam. The vertical repeatability of this method was estimated to be $\pm 2.5 \mathrm{~mm}$ based on consecutive surveys without terrain change. Manufacturer reported accuracy was $\pm 1.0 \mathrm{~mm}$. Since the primary objective for the erosion bridge measurements was measuring the terrain change, vegetation encountered along the transects was delicately pulled aside to ensure the laser was striking the ground.

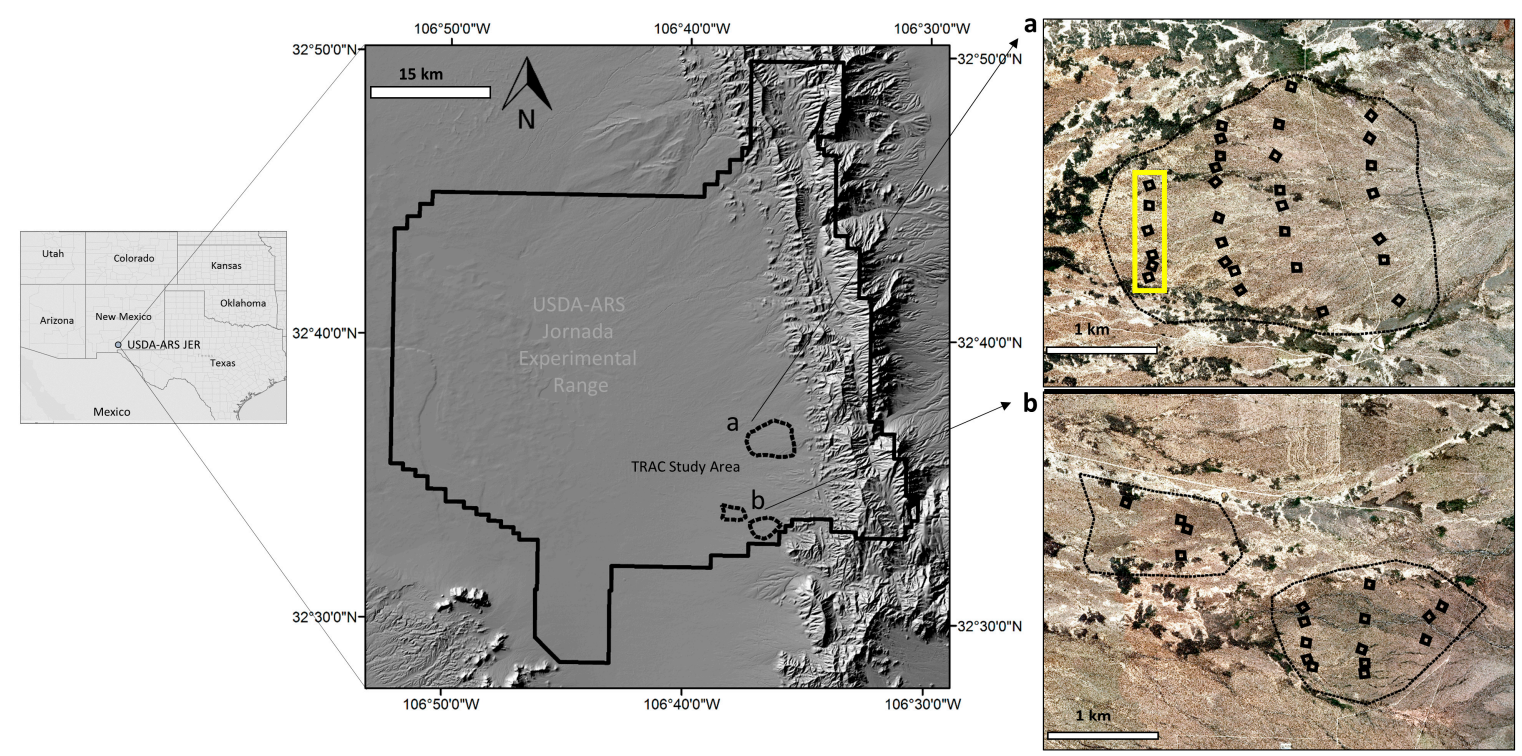

Figure 1. This study was conducted at the USDA-Agricultural Research Service Jornada Experimental Range outside of Las Cruces, NM. Our six test plots (within yellow box) are a subset of the threshold resistance and connectivity (TRAC) project which is investigating the impact of roads and vehicular traffic on dryland landscapes.

\subsection{Image Acquisition}

We acquired UAS imagery in June 2014 and February 2015 within a few days of the erosion bridge measurements using an MLB BAT4 fixed-wing (Figure 2; Table 1) which weighs $59 \mathrm{~kg}$ and has a $4 \mathrm{~m}$ wingspan. The aircraft was powered by an $110 \mathrm{cc} 2$-stroke engine and required a runway (152 m minimum) for take-off and landing. The BAT4 has a telemetry range of over $16 \mathrm{~km}$ and has an endurance of approximately five hours before refueling. These characteristics make it an ideal platform to image large landscapes and flight tests have shown that it can image nearly $13 \mathrm{~km}^{2}$ (1300 ha) in $2.5 \mathrm{~h}$ at $213 \mathrm{~m}$ above ground level (AGL). Operation of the UAS in national and restricted airspace was conducted under a Federal Aviation Administration certificate of authorization held by New Mexico State University Physical Science Laboratory.

For this study, the aircraft flew on average $152 \mathrm{~m}$ AGL which yielded a ground sampling distance of $\sim 2.7 \mathrm{~cm}$ and an image footprint of $156 \times 104 \mathrm{~m}$. The onboard sensor was a 21 megapixel Canon EOS 5D Mark II DSLR and a Canon EF $35 \mathrm{~mm}$ lens. It was mounted within the fuselage with a lens hole cut on the bottom of the aircraft. The entire acquisition mission was executed autonomously using Cloud Cap Piccolo autopilot and the mission planning and flight software Piccolo Command Center (www.cloudcaptech.com). Both acquisitions used the same flight plan. Planned image forward overlap was $66 \%$ and image sidelap was $66 \%$. The forward overlap was lower than typical ( $80 \%)$ due to camera triggering speed. All images were intended to be vertical (nadir). Three parallel flight lines were in north-south orientation and eighteen parallel flight lines were in east-west orientations (Figure 2c) to ensure multiple views for all surfaces. For each acquisition date, the flight plan was executed twice to ensure target coverage and image overlap in case of camera triggering problems or 
slight variations in roll, pitch, and yaw at the time of exposure. Each point on the ground was captured on average in 20 images. Images were captured in RAW format and converted to 16-bit TIFF for image processing. Images were taken within a few hours of solar noon to minimize shadowing. There was more shadowing, however, in the February 2015 acquisition because of the lower winter sun angle.
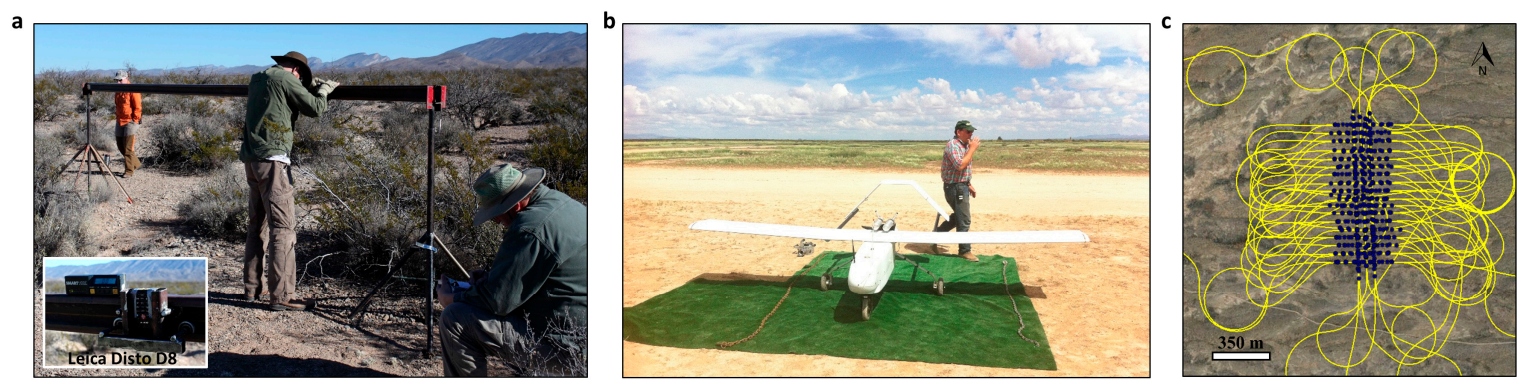

Figure 2. (a) We measured surface elevation profiles using a laser range finder (inset map) attached and slid along a $6.1 \mathrm{~m}$ erosion bridge; (b) We acquired high-resolution imagery using an MLB BAT4 fixed-wing unmanned aerial vehicle; (c) The flight path for the image acquisition in June 2014 and February 2015. The yellow line is the flight path and the blue dots represent the image locations.

Repeat DTM surveys require highly accurate spatial references to ensure proper scaling, rotation, and georeferencing of the 3D model. Though direct georeferencing with onboard GNSS and inertial measurement units (IMU) has become common, imagery products are still generally more accurate and precise using a network of surveyed ground control points (GCPs) [3,50]. In terms of GCP patterns, recent literature has suggested that GCP networks should be evenly distributed [12] and generally surround the area of interest due to DTM quality deteriorating outside of GCP envelopes [51,52]. Regarding GCP density (quantity per area), references from traditional aerial photogrammetry suggest locating GCPs at the beginning and end of each flight line along with interior GCPs located every 3-5 images [53-55]. Some SfM studies have reported the highest accuracies with GCPs densities similar to the traditional approach $[12,30]$. Beyond this density, there appears to be a saturation point where additional GCPs offer no further improvement [56-58]. Other research has shown that GCPs quantities can be greatly reduced with a well-defined camera model and proper weighting of tie point and marker accuracy [59].

We surveyed 12 GCPs in each plot with a Leica TS02 total station (http:/ /leica-geosystems.com). Comparative analysis showed that there was no significant difference in image product quality using 3 GCPs and 12 GCPs. Accordingly, we used 3 GCPs per plot as ground referencing during SfM processing and used the remaining 9 locations as check points (Figure 3b). Our main sources of errors were centering the prism pole at the GCP locations and the uncertainties in angle and distance measurements observed with the total station. Following the procedure described by Baykal et al. [60], with a $1.0 \mathrm{~mm}$ centering error for the prism pole [61] and the published accuracy of the Leica TS02 total station [62], the estimated relative positional uncertainty of the GCPs is approximately $1.5-1.7 \mathrm{~mm}$. Each plot was surveyed separately in its own local coordinate system. We then converted the local coordinates into universal transverse Mercator (UTM) coordinate system by determining the $x, y$, z position of the 3 GCPs in each plot using a Trimble GeoXH 6000 GNSS receiver. We differential corrected the coordinates with data from a Continuously Operating Reference Station (CORS) using the Trimble's GPS Pathfinder Office (http:/ / www.trimble.com/) (3D positional accuracy of $10 \mathrm{~cm}$ ). The local coordinates of the check points were projected into UTM using ArcGIS 10.2 (ESRI, Redlands, CA, USA). This total station/GNSS method of referencing was done to have the accuracy of a total station survey but in a real world coordinate system making it GIS ready for future analysis with additional data sets. The GCP/check point targets were $17 \mathrm{~cm}$ diameter black plastic lids with a $5 \times 5 \mathrm{~cm}$ white square in the center. For each flight, ten GCPs were placed on the permanent nails that mark the ends of each erosion bridge (Figure 3b). Two additional targets were placed near the 
center of each plot, attached to PVC stakes in the ground. The same GCP/check points were used for 2014 and 2015 imagery. Image exposure location and orientation information recorded by the BAT4's onboard GNSS/IMU was not used for referencing because of large positional errors due to time synchronization problems between the camera shutter and the GNSS/IMU.

Table 1. Acquisition and processing specifications for June 2014 and February 2015 imagery.

\begin{tabular}{cc}
\hline Aircraft & Bat 4 Fixed-Wing \\
Sensor & Canon EOS 5D Mark II, 21 megapixels \\
Canon EF 35 mm lens \\
Flying height above ground level (m) & $\sim 152 \mathrm{AGL}$ \\
Image Forward Overlap (\%) & 66 \\
Image Side Overlap (\%) & 66 \\
Image Ground Footprint $(\mathrm{m})$ & $156 \times 104$ \\
Ground sampling distance $(\mathrm{cm})$ & $\sim 2.7$ \\
Image Count & $25-35$ images per plot \\
Avg. Point density (points· $\left.\mathrm{m}^{-2}\right)$ & 1444 \\
DTM cell size $(\mathrm{cm})$ & 5 \\
\hline
\end{tabular}

\subsection{Image Processing}

We used SfM photogrammetry software Agisoft Photoscan version 1.1.6 build 2038 (http:// www.agisoft.ru) to create 3D point clouds, digital surface models (DSMs), and orthomosaics for each plot individually. The first step consisted of photo alignment and creation of sparse point clouds. Agisoft Photoscan uses algorithms similar to Scale Invariant Features Transform (SIFT) [63] to search for features that are identifiable in multiple images and through an iterative bundle adjustment determines the location and orientation of all cameras in the block as well as calculates 3D coordinates of the features in a sparse point cloud. Internal camera parameters were not known a priori, however, self-calibration provided by Agisoft Photoscan was used as it has been shown to produce accuracy results similar to pre-calibration approaches [64]. No erroneously located sparse points were detected (e.g., sinkers and flyers) so no manual point filtering was conducted. Next, we manually identified GCPs in 2 images for each plot which enabled Agisoft Photoscan to estimate the locations of the GCPs in all other images based on the scene geometry. The estimated GCP locations were checked and adjusted to the center of each GCP. Coded targets that Agisoft Photoscan can automatically identify were experimented with but were unreliable at this image scale. We performed the linear Helmert transformation to convert the scene's arbitrary coordinates into UTM Zone 13, WGS84 (the coordinates of the GCPs), then potential non-linear errors were removed by optimizing the scene with another bundle adjustment using the GCP coordinates [65]. Within the bundle adjustment we specified the following measurement accuracies: marker accuracy, $3 \mathrm{~cm}$; marker accuracy, 0.1 pixels; and tie point accuracy, 4 pixels. The latter two parameters were default in Agisoft Photoscan, while the first parameter was an estimate of accuracy using the total station/GNSS workflow. The lens parameters we optimized included focal length (f), principal point coordinates (cx, cy), radial distortion parameters $(\mathrm{k} 1, \mathrm{k} 2, \mathrm{k} 3)$, affinity and non-orthogonal (b1, b2), tangential distortion (p1, p2). We specified "ultra-high" density and "mild filtering" settings for dense point cloud creation which generated an average density of 1444 points. $\mathrm{m}^{-2}$ (Table 1, Figure 3c). A more detailed description of the SfM workflow can be found in Snavely et al. [16], Westoby et al. [20], Smith et al. [66], and Eltner et al. [55].

In repeat topographic surveys, the presence of shrubs and other vegetation can confound our ability to quantify soil change. Accordingly, we identified and filtered out all vegetation in the point clouds. We used the "Classify Ground Points" tool in Agisoft Photoscan to identify ground and non-ground points based on their topographic position compared to surrounding points. The point cloud was first divided into a grid of equally sized cells, and the point with the lowest elevation was identified as being ground. Additional ground points were identified based on a user specified distance and angle from the original ground point. After testing each of the parameters we found 
the best results had a cell size of $0.75 \mathrm{~m}$, a maximum angle to other ground points of 1 degree, and maximum distance of $5 \mathrm{~cm}$ from the originally identified ground point. See also Cunliffe et al. [67] for similar a methodology used to filter vegetation in a semi-arid shrubland. To have greater control over the interpolation process (Agisoft Photoscan does not publish full methods), we exported only the ground points into Log ASCII Standard (LAS) files, then imported them into ArcGIS 10.2 as ESRI LASD files. We converted the point clouds to DTMs) using natural neighbor interpolation with a spatial resolution of $5 \mathrm{~cm}$. Areas where the points had been removed because they were identified as vegetation, became gaps in the DTMs represented as "no data". Some manual editing was necessary to completely remove vegetation areas from the DTMs due to omission by the ground point classification in Agisoft Photoscan. We assessed the quality of the DTMs by comparing northing, easting, and elevation coordinates with the 9 check points in each plot. We subtracted the 2014 DTM from the 2015 DTM on a cell by cell basis to make a DTM difference image for each of the six plots. Because this was a methodological test and because minimal erosion was expected between acquisition dates, we did not transform the DTM difference measurements into estimates of soil volume and mass. Dense point clouds, DSMs, and orthomosaics with the vegetation still present were also generated and exported from Agisoft Photoscan for visualization purposes.
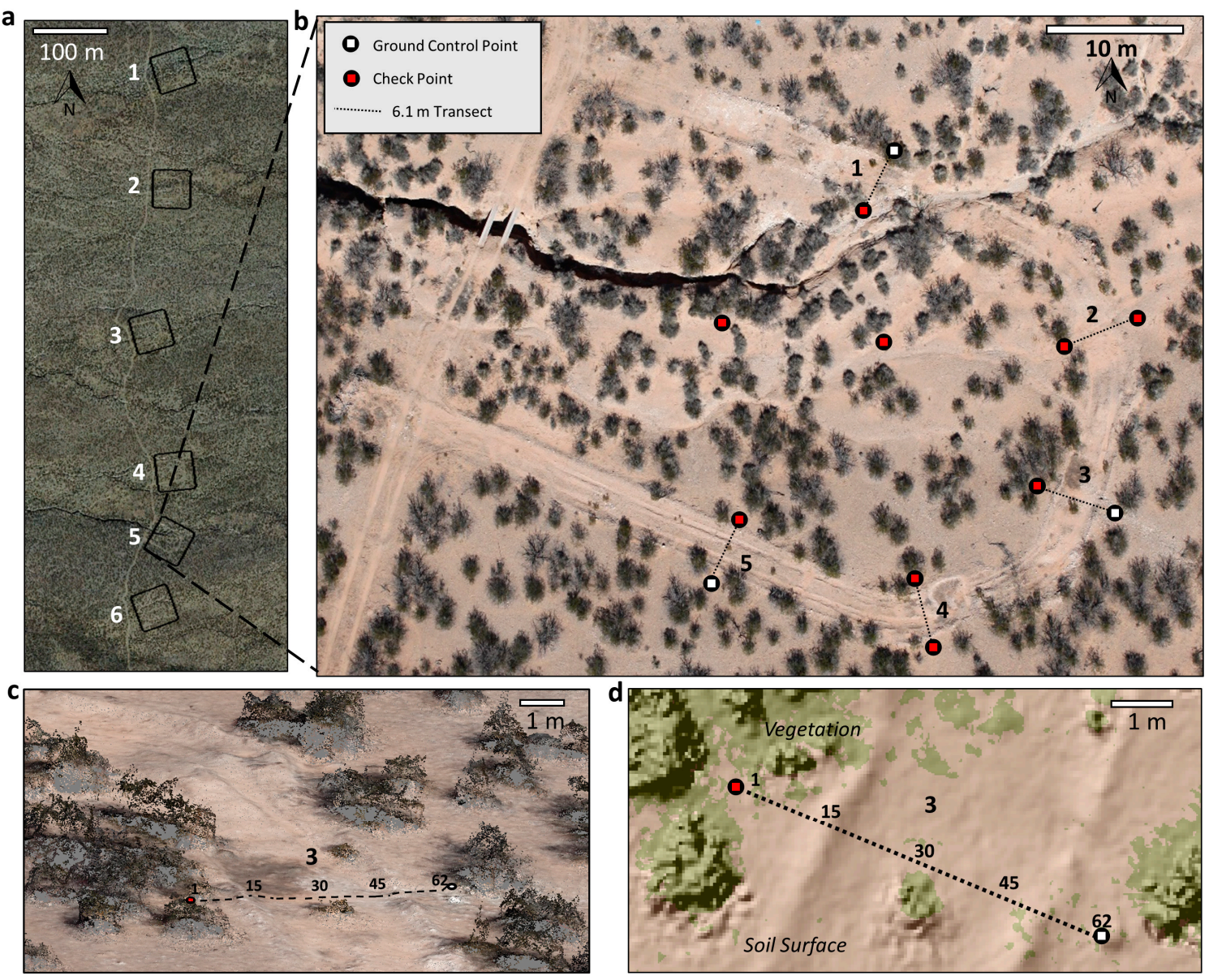

Figure 3. (a) Six $50 \times 50 \mathrm{~m}$ test plots were chosen to compare laser range finder (erosion bridge) and UAS-based digital terrain model (DTM) methods for representing surface topography; (b) For each plot we measured surface elevation profiles along 5 transects using both methods. The DTMs were reconstructed using structure-from-motion photogrammetry methods referenced with 3 ground control points and were assessed with 9 check points; (c) Point clouds were created for each plot as an intermediate step to build DTMs; (d) Along each transect we compared the elevations between the erosion bridge and DTM 62 times $(10 \mathrm{~cm}$ spacing). 


\subsection{Assessing Agreement between Erosion Bridge and DTMs}

Using the colored point clouds to visual identify the ends of the topographic transects (marked with targets), we extracted elevations from the DTMs using the "interpolation line" tool available in ArcMap 3D Analyst toolbar. The extracted profile is intended to be the exact area measured by the erosion bridge to facilitate direct comparison between the two methods (Figure 3d). The erosion bridge laser measurements (originally distance to ground) were converted to elevation in the same UTM coordinate system as the DTMs by assigning the first laser measurement (nail) the same GNSS coordinate as the GCP. The rest of the erosion bridge elevation values were calculated as a vertical deviation from the beginning nail elevation. Using this methodology, the erosion bridge topographic profiles were not a completely independent "check" data set and testable only for z-value elevation. This was done deliberately to compare the photogrammetric DTM methods with erosion bridge methods independent from the inherent inaccuracies of referencing tools such as GNSS.

Erosion bridge measurements were taken every $10 \mathrm{~cm}$, while DTMs had $5 \mathrm{~cm}$ cell sizes. Using an $R$ script ( $R$ version 3.1.1.; [68], we paired a DTM height with its corresponding erosion-bridge height every $10 \mathrm{~cm}$ along the transect. The remaining DTM heights that were not paired (half) were removed from the analysis. There were a total of 62 pairs per transect and 1860 pairs across all transects in the 6 plots. Because the measurements were taken twice (June 2014, February 2015) the total number of comparative height pairs was 3720 . We removed from the analysis the height pairs corresponding to the nails at both ends of the transects because they were used to convert the erosion bridge data to UTM coordinates, and thus not independent. On several of the transects, shrubs were present. To make the erosion-bridges directly comparable with the DTMs, we removed any height pairs that had the presence of vegetation (i.e., vegetation pulled aside to laser the ground) because vegetation areas were already removed from the DTMs. After removing height pairs influenced by vegetation and nail pairs, we had 3314 pairs for analysis.

\subsection{Assessing DTM Repeatability}

A common method for quantifying repeatability is propagating accuracy error in each digital elevation model (DEM; a generic term encompassing both DTMs and DSMs; see Lane et al. 2003 [69]). For example, Brasington et al. [70] and Wheaton et al. [26] showed how individual errors in a DEM can be propagated in a DEM difference as:

$$
\delta u_{D o D}=\sqrt{\left(\delta z_{\text {new }}\right)^{2}+\left(\delta z_{\text {old }}\right)^{2}}
$$

where $\delta u_{D o D}$ is the propagated error in the differenced DEM, and $\delta z_{\text {new }}$ and $\delta z_{\text {old }}$ are the individual errors in the first and second DEM, respectively. Another method measures the height of unchanged features during the time-series which could include natural features such as rocks or a network of validation points [71,72]. Comparison of DEM change to change measured by the erosion bridge offers a third method of quantifying repeatability. Deviation of the DEM change estimates from the erosion bridge change measurements ("true change" for the purposes of this study) is an indication of the repeatability of the DEM method. Using this method produced 1657 estimate of repeatability, far more than the check point dataset $(n=54)$ or locating invariant features (e.g., rocks) in the imagery of each plot. Because photogrammetric processing was separate for each plot, we assessed repeatability for each plot individually.

Based on the quantified repeatability error we used a statistical threshold to separate model error in DTM differencing from actual surface change. We used a $t$-distribution $95 \%$ confidence interval where the upper and lower 2.5 percentiles (i.e., $<2.5$ percentile and $>97.5$ percentiles) were considered to be actual surface change. Values $>2.5$ percentile and $<97.5$ percentile were discarded as model error. This method of thresholding represents a conservative estimate of change which limits type I errors (i.e., reporting soil movement when it did not occur). Setting a threshold level of detection should reflect the specific application of the repeat topographic survey and the potential costs of false positives 
and false negatives. For our application, we did not want to wrongly attribute soil erosion to vehicular driving on dirt roads if it did not actually happen.

\section{Results}

\subsection{DTM Comparison with Check Points}

We assessed the easting, northing, and elevation accuracy of the DTMs through a traditional method of comparing image coordinates with independent check point coordinates. The easting and northing RMSE for all plots was $1.1 \mathrm{~cm}$ and $1.5 \mathrm{~cm}$, respectively for the June 2014 acquisition (Table 2). The easting and northing RMSE for the February 2015 acquisition was nearly identical with RMSE of $1.1 \mathrm{~cm}$ and $1.1 \mathrm{~cm}$, respectively. The elevation RMSE for all plots was $2.3 \mathrm{~cm}$ in the June 2014 acquisition and February 2015 acquisition.

Table 2. Check point coordinates minus DTM coordinates.

\begin{tabular}{|c|c|c|c|c|c|c|c|c|c|c|c|}
\hline \multirow{2}{*}{ Plot } & \multirow{2}{*}{$\begin{array}{l}\text { Acquisition } \\
\text { Date }\end{array}$} & \multirow{2}{*}{$\begin{array}{l}\text { Check } \\
\text { Points n }\end{array}$} & \multicolumn{3}{|c|}{ Mean Difference (cm) } & \multicolumn{3}{|c|}{ Absolute Mean Difference (cm) } & \multicolumn{3}{|c|}{ RMSE (cm) } \\
\hline & & & Easting & Northing & Elevation & Easting & Northing & Elevation & Easting & Northing & Elevation \\
\hline \multirow[b]{2}{*}{1} & June 2014 & 9 & -0.1 & -0.9 & -0.2 & 1.0 & 0.9 & 1.7 & 1.1 & 1.1 & 2.2 \\
\hline & February 2015 & 9 & 0.0 & -1.0 & 0.2 & 0.8 & 1.3 & 0.9 & 1.0 & 1.8 & 1.2 \\
\hline \multirow{2}{*}{2} & June 2014 & 9 & -0.4 & 0.8 & -1.0 & 1.0 & 1.1 & 3.0 & 1.7 & 1.7 & 4.0 \\
\hline & February 2015 & 9 & -0.5 & 0.2 & -1.1 & 1.1 & 0.4 & 2.5 & 1.4 & 0.5 & 3.8 \\
\hline \multirow{2}{*}{3} & June 2014 & 9 & -0.4 & 0.1 & -0.2 & 0.9 & 0.7 & 0.9 & 1.1 & 0.9 & 1.2 \\
\hline & February 2015 & 9 & -0.6 & -0.0 & 0.1 & 0.9 & 0.6 & 1.3 & 1.3 & 0.9 & 1.4 \\
\hline \multirow{2}{*}{4} & June 2014 & 9 & 0.2 & 0.1 & 0.1 & 0.3 & 0.6 & 1.1 & 0.4 & 0.9 & 1.4 \\
\hline & February 2015 & 9 & 0.6 & -0.5 & 1.0 & 0.6 & 0.9 & 1.1 & 0.7 & 1.1 & 1.3 \\
\hline \multirow[b]{2}{*}{5} & June 2014 & 9 & 0.4 & 0.3 & 1.7 & 0.8 & 1.4 & 2.0 & 1.0 & 2.6 & 2.7 \\
\hline & February 2015 & 9 & -0.5 & 0.3 & 2.0 & 1.2 & 1.0 & 2.9 & 1.3 & 1.1 & 3.5 \\
\hline \multirow[b]{2}{*}{6} & June 2014 & 9 & -0.3 & 0.3 & 0.0 & 0.7 & 0.6 & 0.9 & 0.9 & 0.7 & 1.1 \\
\hline & February 2015 & 9 & 0.1 & 0.2 & 0.1 & 0.6 & 0.8 & 0.4 & 0.8 & 0.9 & 0.5 \\
\hline \multirow[b]{2}{*}{ All } & June 2014 & 54 & -0.1 & 0.1 & 0.0 & 0.8 & 0.9 & 1.6 & 1.1 & 1.5 & 2.3 \\
\hline & February 2015 & 54 & -0.1 & -0.1 & 0.4 & 0.9 & 0.8 & 1.5 & 1.1 & 1.1 & 2.3 \\
\hline
\end{tabular}

DTM precision (repeatability) between acquisition dates was determined by subtracting 2014 check point ground coordinates from 2015 check point ground coordinates. Precision RMSE was estimated to be 1.4, 1.6, and $1.7 \mathrm{~cm}$ for easting, northing, and elevation, respectively (Table 3).

Table 3. DTM precision (repeatability) calculated by subtracting 2014 check point image coordinates from 2015 check point image coordinates.

\begin{tabular}{ccccccccccc}
\hline \multirow{2}{*}{ Plot } & $\begin{array}{c}\text { Check } \\
\text { Points n }\end{array}$ & \multicolumn{3}{c}{ Mean Difference (cm) } & \multicolumn{3}{c}{ Absolute Difference (cm) } & \multicolumn{3}{c}{ RMSE (cm) } \\
\cline { 3 - 10 } & & Easting & Northing & Elevation & Easting & Northing & Elevation & Easting & Northing & Elevation \\
\hline 1 & 9 & -0.2 & 0.1 & -0.5 & 1.0 & 1.2 & 1.4 & 1.2 & 1.7 & 2.0 \\
2 & 9 & 0.0 & 0.6 & 0.1 & 1.5 & 1.0 & 1.1 & 1.9 & 1.5 & 1.4 \\
3 & 9 & 0.1 & 0.1 & -0.3 & 0.9 & 0.9 & 1.4 & 1.1 & 1.2 & 1.6 \\
4 & 9 & -0.3 & 0.6 & -0.9 & 0.5 & 1.2 & 1.4 & 0.6 & 1.3 & 1.7 \\
5 & 9 & 1.0 & 0.0 & -0.3 & 1.7 & 1.5 & 1.6 & 1.8 & 2.3 & 2.1 \\
6 & 9 & -0.5 & 0.0 & -0.1 & 0.8 & 0.6 & 0.9 & 1.0 & 0.7 & 1.0 \\
All & 54 & 0.0 & 0.2 & -0.3 & 1.1 & 1.1 & 1.0 & 1.4 & 1.6 & 1.7 \\
\hline
\end{tabular}

\subsection{Agreement between Aerial DTMs and Erosion Bridges (Accuracy)}

Comparing the topographic transects measured by the aerial DTMs and the erosion bridges produced vertical RMSE of $2.9 \mathrm{~cm}$ and $3.2 \mathrm{~cm}$ for all plots in June 2014 and Feb. 2015, respectively (Table 4). Except for plot 5, the DTMs in each of the plots in both 2014 and 2015 were reconstructed with a slight systematic higher elevation on average compared with the erosion bridges. DTM and erosion bridge elevation profiles for Plot 5 for each year along with the topographic change from one year to the next are shown in Figure 4a (graphs for remaining plots in Appendix A). 

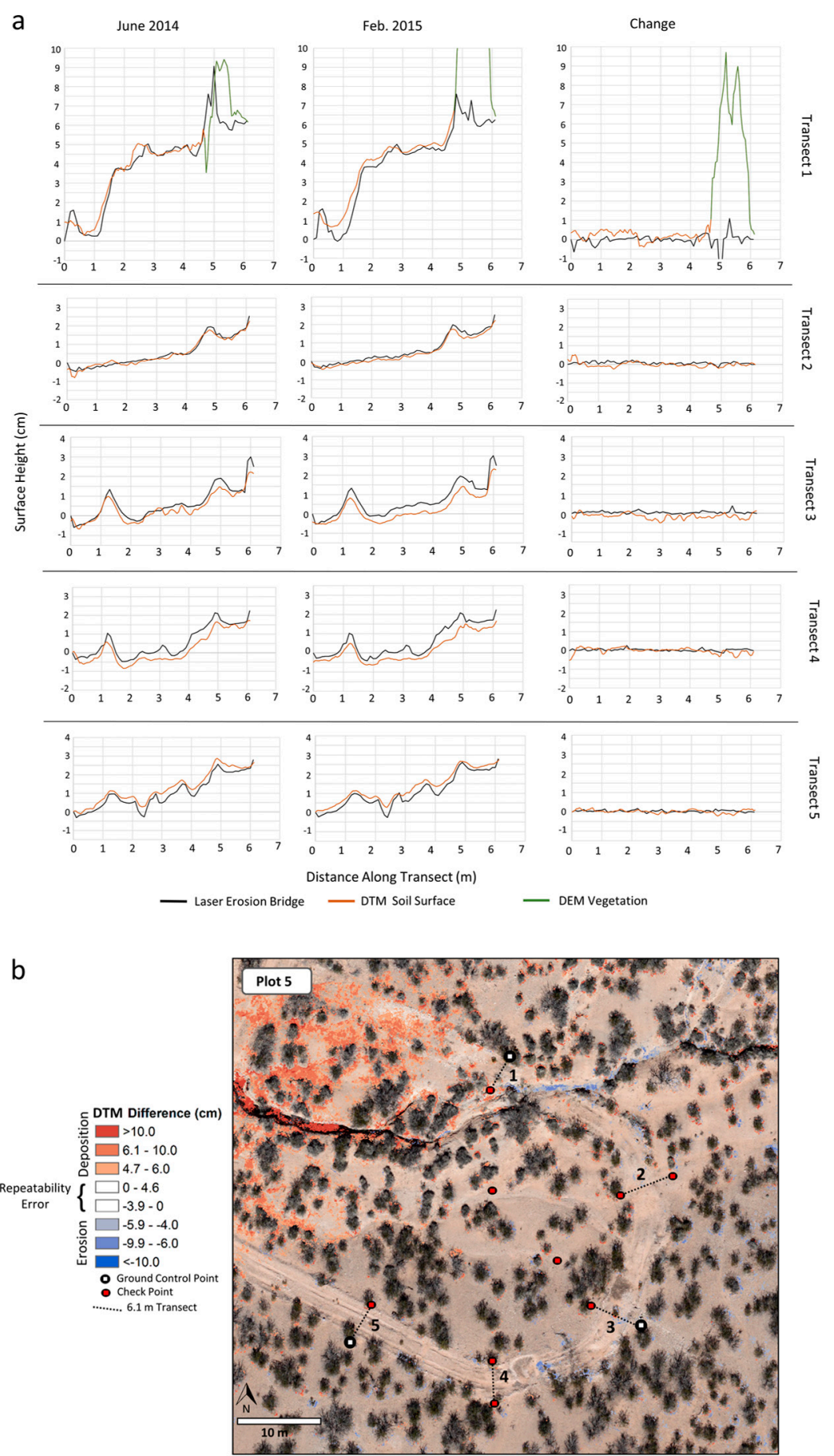

Figure 4. (a) Surface topographic profiles from Plot 5 measured with erosion bridges and digital elevation models (DSMs) reconstructed from UAS imagery. The surface heights (y-axis) are shown as a vertical difference from the first erosion bridge height for easier interpretation and comparison across graphs. The large differences between erosion bridge and DSM surface height measurements at the end of Transect 1 were due to the presence of vegetation. All height pairs with vegetation influence were not included in the accuracy and precision analyses; (b) DTM difference image for plot 5 overlaid on UAS-based orthophotos. Blue colors represent elevation decrease (erosion) and the red colors represent elevation increase (deposition) from June 2014 to February 2015. Transparent areas are within the threshold of repeatability error as determined by the difference between the erosion bridge change and DTM change along the transects. The indicated deposition in the northwest corner of the plot is likely DTM error caused by 'doming' effect outside of the GCP envelope, as opposed to real surface change. 
Table 4. Erosion bridge vertical measurements minus digital terrain model measurements.

\begin{tabular}{cccccc}
\hline Plot & Acquisition Date & Sample Size n & Mean Difference (cm) & Absolute Mean Difference (cm) & RMSE (cm) \\
\hline \multirow{2}{*}{1} & June 2014 & 249 & -2.2 & 2.5 & 2.9 \\
& February 2015 & 249 & -1.1 & 1.7 & 2.3 \\
\hline \multirow{2}{*}{2} & June 2014 & 292 & -1.2 & 1.6 & 2.1 \\
& February 2015 & 292 & -0.9 & 1.9 & 3.0 \\
\hline \multirow{2}{*}{3} & June 2014 & 298 & -2.1 & 2.2 & 2.6 \\
& February 2015 & 298 & -0.3 & 1.5 & 2.2 \\
\hline \multirow{2}{*}{4} & June 2014 & 278 & -1.7 & 2.6 & 3.4 \\
& February 2015 & 278 & -1.7 & 2.5 & 4.8 \\
\hline \multirow{2}{*}{5} & June 2014 & 285 & 0.4 & 2.4 & 3.0 \\
& February 2015 & 285 & 0.7 & 3.1 & 3.7 \\
\hline \multirow{2}{*}{6} & June 2014 & 255 & -2.5 & 2.6 & 3.1 \\
& February 2015 & 255 & -1.7 & 2.0 & 2.4 \\
\hline \multirow{2}{*}{ All } & June 2014 & 1657 & -1.5 & 2.3 & 2.9 \\
& February 2015 & 1657 & -0.8 & 2.1 & 3.2 \\
\hline
\end{tabular}

\subsection{DTM Repeatabilty}

Across all plots the vertical repeatability of the DTMs, as measured by the difference between erosion bridge change and DTM change, had an average RMSE of $2.8 \mathrm{~cm}$ (Table 5). In individual plots, RMSE ranged from $2.2 \mathrm{~cm}$ to $4.4 \mathrm{~cm}$. Applying the $95 \% \mathrm{CI}$ threshold, the average vertical error (undetectable surface change) was between $-4.7 \mathrm{~cm}$ and $6.1 \mathrm{~cm}$. Vertical surface change detectability varied between individual plots. The lower 95th percentile threshold ranged between $-2.0 \mathrm{~cm}$ and $-8.8 \mathrm{~cm}$ while the upper 95th percentile threshold ranged between $4.6 \mathrm{~cm}$ and $8.6 \mathrm{~cm}$.

The only anomalies in the repeatability results occurred in Plot 4 where 8 measurements from the erosion bridge showed deepening of a narrow rill that was not detected in the DTMs (Figure A4). Therefore the difference between the erosion bridge change and DTM change at this site was much larger than all other repeatability measures in the study. These values had a disproportionately large effect on the threshold of this plot but were retained in the analysis to demonstrate some of the discrepancies between the two methods of topographic measurement.

In comparison with the check point benchmark, accuracy and precision using the erosion bridge benchmark was slightly worse. This was not altogether unexpected because the check point benchmark was a comparison of DTMs with survey grade positioning of flat discs. The erosion bridge benchmark method was more challenging given the range of surface roughness of the transects. In addition, there was a small spatial mismatch in the way the terrain was measured between DTMs and erosion bridge laser measurements. The erosion bridge laser measured a point on the ground less than a millimeter in size while the DTM was an interpolation of 3-4 points within a $5 \mathrm{~cm}$ cell.

\subsection{Topographic Change}

Over the 9 month span between data collections there was very little soil movement. The erosion bridge measurement showed an average positive vertical change of only $4 \mathrm{~mm}$ (Table 5). The DTMs showed an average change of $-2 \mathrm{~mm}$ between acquisitions. This indicates that there is a small but systematic shift between the ground and imagery methods. The cause of this shift is unknown in this case, but can easily be corrected if the offset remains stable in further investigations. Maps of DTM differencing showed very little surface change within the area enclosed by the GCPs deep enough to cross the threshold of true surface change (Figure $4 \mathrm{~b}$ as example; other maps are in Appendix A). Only a few areas within arroyos (dry water channels) experienced significant soil change. An exception to this can be seen in the northwest corner of plot 5 where there is indication of significant soil deposition. This is not true surface change but are instead DTMs errors that will be described in more detail in the discussion. 
Table 5. Digital elevation model (DTM) vertical repeatability error as measured by comparing the DTM change with erosion bridge change (erosion bridge change minus DTM change). Because structure-from-motion processing was carried out separately for each plot to create DTMs, we assessed repeatability error individually for each plot.

\begin{tabular}{|c|c|c|c|c|c|c|c|c|c|c|c|}
\hline \multirow[t]{2}{*}{ Plot } & \multirow[t]{2}{*}{ Sample n } & \multirow{2}{*}{$\begin{array}{l}\text { Mean Erosion } \\
\text { Bridge Change } \\
(\mathrm{cm})\end{array}$} & \multirow{2}{*}{$\begin{array}{l}\text { Absolute Mean } \\
\text { Erosion Bridge } \\
\text { Change (cm) }\end{array}$} & \multirow{2}{*}{$\begin{array}{l}\text { Mean DTM } \\
\text { Change (cm) }\end{array}$} & \multirow{2}{*}{$\begin{array}{l}\text { Absolute } \\
\text { Mean DTM } \\
\text { Change (cm) }\end{array}$} & \multirow{2}{*}{$\begin{array}{c}\text { Erosion Bridge } \\
\text { Change Minus DTM } \\
\text { Change }(\mathrm{cm})\end{array}$} & \multirow{2}{*}{$\begin{array}{l}\text { Standard } \\
\text { Deviation } \\
\quad(\mathrm{cm})\end{array}$} & \multirow{2}{*}{$\begin{array}{l}\text { Absolute Erosion } \\
\text { Bridge Change Minus } \\
\text { DTM Change (cm) }\end{array}$} & \multirow{2}{*}{$\begin{array}{l}\text { Change } \\
\text { Difference } \\
\text { RMSE (cm) }\end{array}$} & \multicolumn{2}{|c|}{$\begin{array}{l}\text { 95\% Confidence } \\
\text { Interval }(\mathrm{cm})\end{array}$} \\
\hline & & & & & & & & & & Lower & Upper \\
\hline 1 & 249 & 0.3 & 0.5 & -0.7 & 1.9 & 1.0 & 2.4 & 2.0 & 2.6 & -3.6 & 5.8 \\
\hline 2 & 292 & 0.5 & 0.7 & 0.2 & 1.4 & 0.2 & 2.4 & 1.6 & 2.4 & -4.4 & 5.0 \\
\hline 3 & 298 & 0.8 & 1.0 & -0.8 & 1.5 & 1.7 & 1.9 & 2.1 & 2.6 & -2.0 & 5.5 \\
\hline 4 & 278 & -0.1 & 1.1 & -0.1 & 1.9 & 0.0 & 4.4 & 2.3 & 4.4 & -8.8 & 8.6 \\
\hline 5 & 285 & 0.4 & 0.7 & 0.0 & 1.3 & 0.3 & 2.1 & 1.6 & 2.2 & -3.9 & 4.6 \\
\hline 6 & 255 & 0.6 & 0.7 & -0.1 & 1.6 & 0.8 & 2.1 & 1.9 & 2.2 & -3.4 & 5.0 \\
\hline All & 1657 & 0.4 & 0.8 & -0.2 & 1.6 & 0.7 & 2.7 & 1.9 & 2.8 & -4.7 & 6.1 \\
\hline
\end{tabular}




\section{Discussion}

\subsection{Comparison with Other Studies}

The vertical accuracy of our UAS-based SfM DTMs were quite similar to other studies using very fine spatial resolution imagery. Gonçalves and Henriques [17] had a vertical RMSE of 2.7-4 cm comparing DTMs to independent check points measured with GNSS. Lucieer et al. [29] reported a vertical RMSE of $4.4 \mathrm{~cm}$ comparing DTMs to ground check points measured with GNSS. Stöcker et al. [31] comparing DTMs to ground check points measured with a total station found RMSE of $Z$ coordinates to be $1.6 \mathrm{~cm}$. Eltner and Schneider [32] reported a 3D RMSE of $9 \mathrm{~mm}$ compared to ground check points measured with a total station and 3D RMSE of $8.7 \mathrm{~mm}$ compared to terrestrial laser scanning. Glendell et al. [73] compared vertically differenced DEMs using terrestrial laser scanning methods against UAS image reconstructions, both with $2 \mathrm{~cm}$ GSD. They found vertical difference RSMEs as low as 5 and $6 \mathrm{~cm}$.

Directly comparing the accuracy of different studies is generally not possible due to the multitude of acquisition and processing specifications. Some of the differences included the original scale of the imagery, overlap, the density of the point clouds, and the methods they used to create a benchmark that have varying levels of inherent accuracies (i.e., GNSS, Total Station, Laser Scanning). However, even with minor mismatches comparing accuracy between studies, it is clear from the literature and this study that fine-scale terrain can be surveyed from UAS-based SfM to accuracies within a few centimeters.

Repeatability of UAS-based SfM DTMs is less reported in the literature for very fine spatial resolution image studies. Our DTMs (absolute mean difference $\pm 1.8 \mathrm{~cm}$ ) were quite similar to a study by Lucieer et al. [13] who looked at static ground areas totaling 205,000 pixels and found the absolute mean difference between two DTMs to be $\pm 1.7 \mathrm{~cm}$. Clapuyt et al. [30] created replications of DTMs using different image sets at one point in time and found mean vertical precision to be $\pm 6 \mathrm{~cm}$. This lower precision was possibly due to less precise GNSS coordinates of check points and sparser point clouds, so it is not directly comparable to our study. Neugirg et al. [28] reported repeatability of DTMs having a standard deviation of $6.2 \mathrm{~cm}$ which was less precise than our DTMs $(2.3 \mathrm{~cm})$.

\subsection{Topographic Surveying for Soil Erosion}

Our results from comparing SfM-generated DTMs to check points, and strong agreement with erosion bridge measurements suggests repeat UAS imagery and SfM processing could replace erosion bridges for a more synoptic landscape assessment of shifting soil surfaces for some studies. For example, with soil surface DTM differencing it may be possible to view landscape-scale effects of the TRAC driving treatments including cumulative effects downstream of the disturbance. Gillan et al. [5], using DTM differencing to estimate soil erosion across the study area following vegetation removal treatments in southern Utah, USA, showed that soil movement to neighboring treatments potentially violated assumptions of treatment independence and was not adequately captured by in-situ soil-surface sampling. The ability to map areas of soil erosion and deposition in landscapes could help increase understanding of soil loss patterns due to road networks and potentially improve our ability to model these dynamic processes. Owing to the difficulty in setting up and calibrating erosion bridges, it is possible only to sample a small portion of the same landscape. Even then, it takes much longer to set up the erosion bridges and take measurements than it does to acquire and process UAS images of the same plots.

However, there is tradeoff between geographic extent and pixel size (i.e., spatial resolution) for surveying soil elevation change. The ability to discern topographic change from UAS-based SfM DTM differencing is lower than that of erosion bridge measurements, meaning SfM DTM differencing requires a larger vertical change of soil to be detectable as it was implemented in this study. Using our strict change threshold $(95 \% \mathrm{CI})$, we could detect soil erosion greater than $4.7 \mathrm{~cm}$ and deposition greater than $6.1 \mathrm{~cm}$ from UAS-based DTM differencing at this image scale. Whether this 
level of precision is suitable for studying or monitoring dryland soil erosion depends on the objective and the cost of making Type I and Type II errors [74]. For the TRAC study, our implementation of a strict threshold was appropriate to avoid Type I errors (i.e., falsely attributing a linkage between vehicle driving and erosion processes). In a monitoring context, the cost of not detecting soil movement may be great enough to warrant relaxing the threshold (i.e., accepting a lower C.I.), thereby improving the detectability of soil movement. An approach that leverages the advantages of both the aerial and ground methods could be workable in some situations. For example, the aerial DTM differencing method we employed could be used to cover a large geographic extent to identify potential problem areas at a coarse resolution. Once the areas have been identified, more precise erosion monitoring methods (lower flying UAS; in situ measurements) could be used to more closely monitor those areas.

\subsection{DTM Errors}

Our calculated DTM differences showed that errors fell into two categories. The first were areas of erroneous soil surface change in the edges or corners of some plots (e.g., Figure $4 b$, northwest corner of Plot 5). This vertical error is likely due to a combination of sources. First, these errors could be caused by slight "doming" affect as described by James and Robson [75] and Eltner and Schneider [32] who showed that nadir-only image acquisitions coupled with SfM self-calibration can lead to poor modeling of camera radial distortion expressed as incorrect lower elevations in the periphery of the 3D scene. Alternatively, our observed areas of incorrect soil surface change could be due to the absence of ground control in the scene periphery and illustrates decay of DTM accuracy outside the area enclosed by the ground control network $[51,52,58,76]$. For our study plots, there does not appear to be a consistent distance outside the enclosed area where accuracy begins to rapidly decline. Some plots displayed increased error immediately outside enclosed area while other plots showed little DTM difference errors for 10's of meters. Variation amongst plots could be due to slight differences in image overlap, accuracy of GCPs, or differences in the original photo alignment.

The second source of error in our DTM differences came from imperfect filtering of vegetation and was expressed as large gains or losses of elevation immediately adjacent to shrubs (i.e., one or both of the DTMs still contained vegetation and when differenced created large changes in elevation). Vegetation filtering is still a significant challenge at this very fine scale and reduces our ability to automate DTM difference processing. Our approach was to use the topographic position of points in the cloud to identify ground points, however, other SfM studies have used a variety of methods to filter vegetation with no clear consensus on a superior workflow $[27,51,52,67,77]$. In our semi-arid shrubland study area, there is a distinct difference in color between the creosote/mesquite shrubs and the bare ground. Coupling color separation with our current use of topographic position filtering could be very successful in terms of separating vegetation from ground.

\subsection{Limitations for Large Landscapes}

There are two main technical constraints to currently adopting UAS-based DTM differencing over large landscapes ( $>200 \mathrm{ha}$ ) in an operational capacity. The first challenge is the ground control requirements. We achieved accuracy and precision RMSE $<3 \mathrm{~cm}$ within the envelope of $3 \mathrm{GCPs}$ for each of our $50 \times 50 \mathrm{~m}$ plots, but expanding this methodology over the entire TRAC study area would necessitate hundreds of GCPs to achieve this same level accuracy and precision. To make quality data collection over large landscapes a more cost effective endeavor, GCP demand needs to be reduced or eliminated. Fortunately, recent research is showing that direct georeferencing using onboard GNSS differentially corrected with base station data can produce similar [78] or slightly worse [50,79] image product accuracy compared with GCPs. More testing is needed with this technology to see if vertical accuracy and precision RMSE $<3 \mathrm{~cm}$ is possible. Ground control demand may also be reduced by the addition of oblique imagery [64,75], well-defined camera models, and proper weighting of tie point and marker accuracy during bundle adjustments $[59,80]$. 
Additionally, the time and computing resources required to replicate our method over the entire TRAC study would also be prohibitive. Even with powerful desktop computers with high-end CPUs, GPUs, and abundant RAM, SfM processing is computationally intensive and can take many days to produce dense point clouds from a large imagery dataset. Additional research into optimization of the number and type (i.e., nadir vs. oblique) of images for high-quality products from SfM is needed. As we continue to collect remotely sensed data at an ever finer resolution and greater extents, cyberinfrastructure that leverages high-performance computing [81] and distributed network processing (i.e., cloud computing) such as Google Earth Engine (https://earthengine.google.com) will become increasingly necessary for storing, processing, and interpreting data for natural resource management in the age of big data.

\section{Conclusions}

Our results demonstrated the utility of SfM DTM differencing using UAS imagery for monitoring changes in soil surface as an alternative to in situ measurements from traditional erosion bridges. Accuracy of the DTMs as measured against erosion bridge was high (RMSE $2.9 \mathrm{~cm}$ and $3.2 \mathrm{~cm}$ in 2014 and 2015, respectively), and correspondence with change as measured by the erosion bridges was also in high agreement (RMSE $2.8 \mathrm{~cm}$ ). The technique we presented allows for a synoptic view of soil movement which provides information on the spatial distribution of erosion and deposition processes that was difficult and expensive to generate previously. However, while collecting the UAS imagery and generating the SfM DTMs for this study was faster than collecting erosion bridge measurements, technical challenges related to the need for ground control networks and image processing requirements must be addressed before this technique could be applied effectively to large landscapes.

Acknowledgments: We are grateful to J. Van Zee and B. Cooper who performed the erosion bridge measurements and C. Maxwell, A. Slaughter and the Bat team for UAS image acquisition. Special thanks goes to J. Herrick for conceiving of the TRAC project. This work was supported by appropriated funding to the USDA-ARS Rangeland Management Research Unit, Jornada Experimental Range. Mention of a proprietary product does not constitute a guarantee or warranty of the products by the U.S. Government or the authors and does not imply its approval to the exclusion of other products that may be suitable.

Author Contributions: J. Gillan and J. Karl conceived and designed the study; J. Gillan conducted all image processing and data analysis; A. Elaksher conducted the ground survey and assisted with image acquisition design; J. Gillan was the primary author and preparer of the manuscript while J. Karl, A. Elaksher, and M. Duniway contributed writing and editing.

Conflicts of Interest: The authors declare no conflict of interest. 


\section{Appendix A}
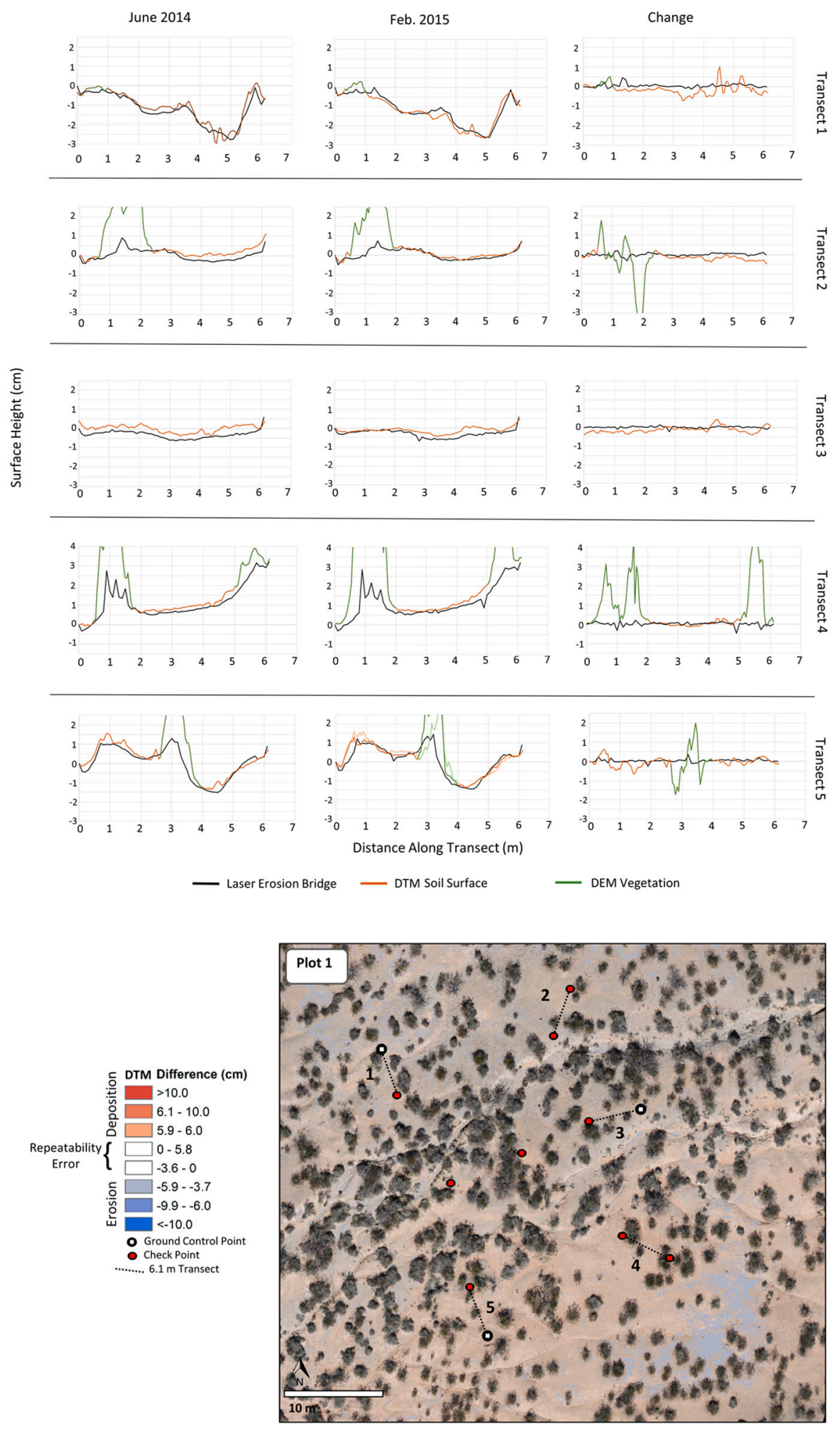

Figure A1. Plot 1 DTM differences and topographic profiles. 
June 2014
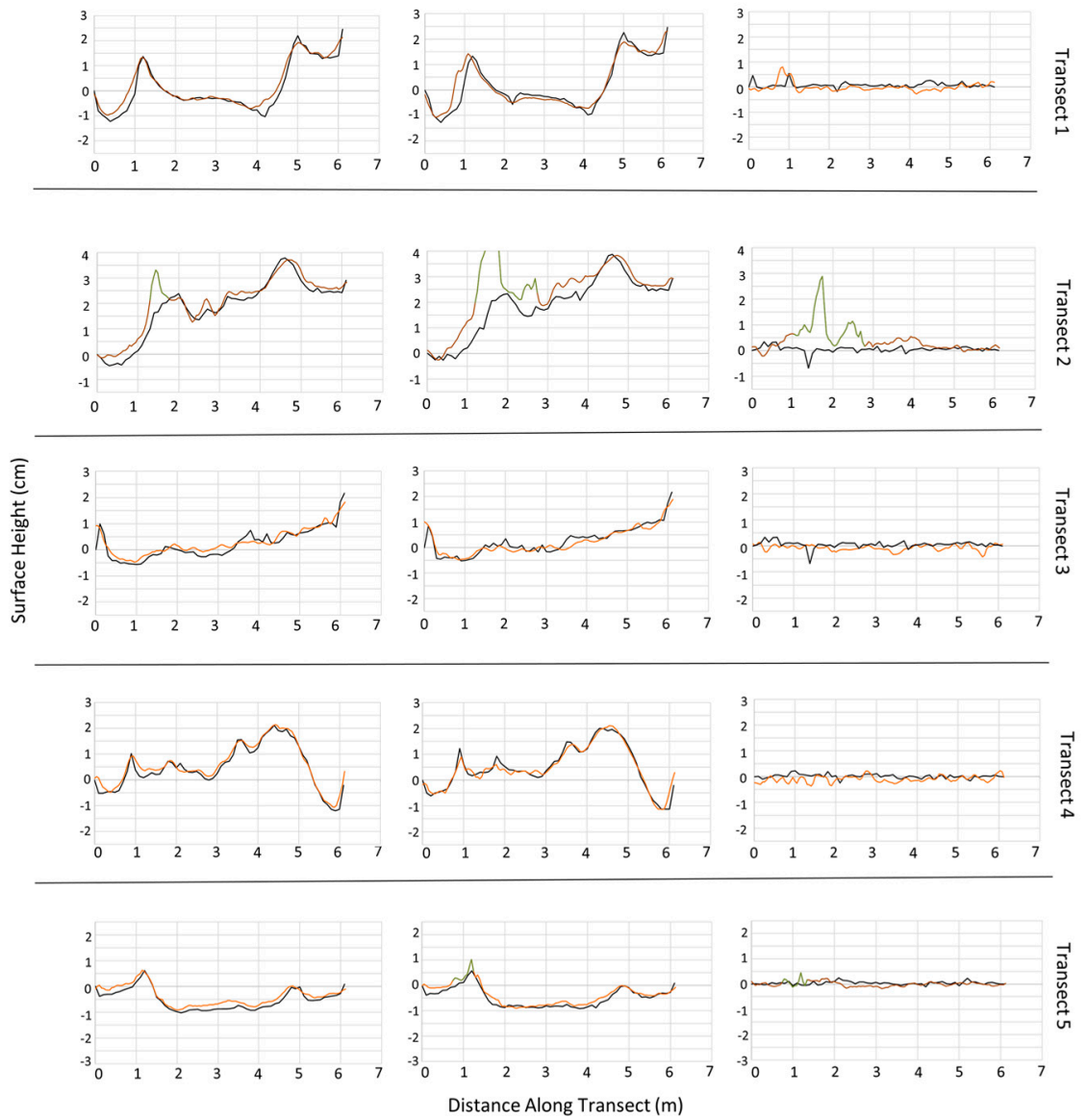

— Laser Erosion Bridge

Along Transect (m)

$$
\text { - DEM Vegetation }
$$

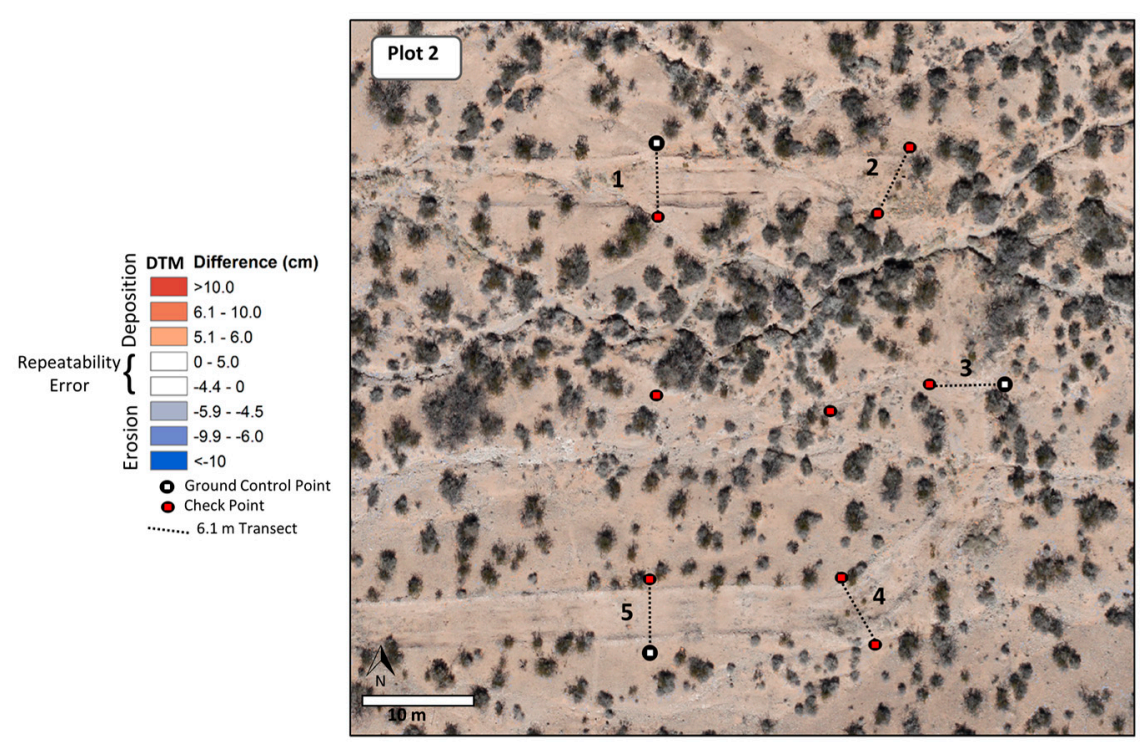

Figure A2. Plot 2 DTM differences and topographic profiles. 

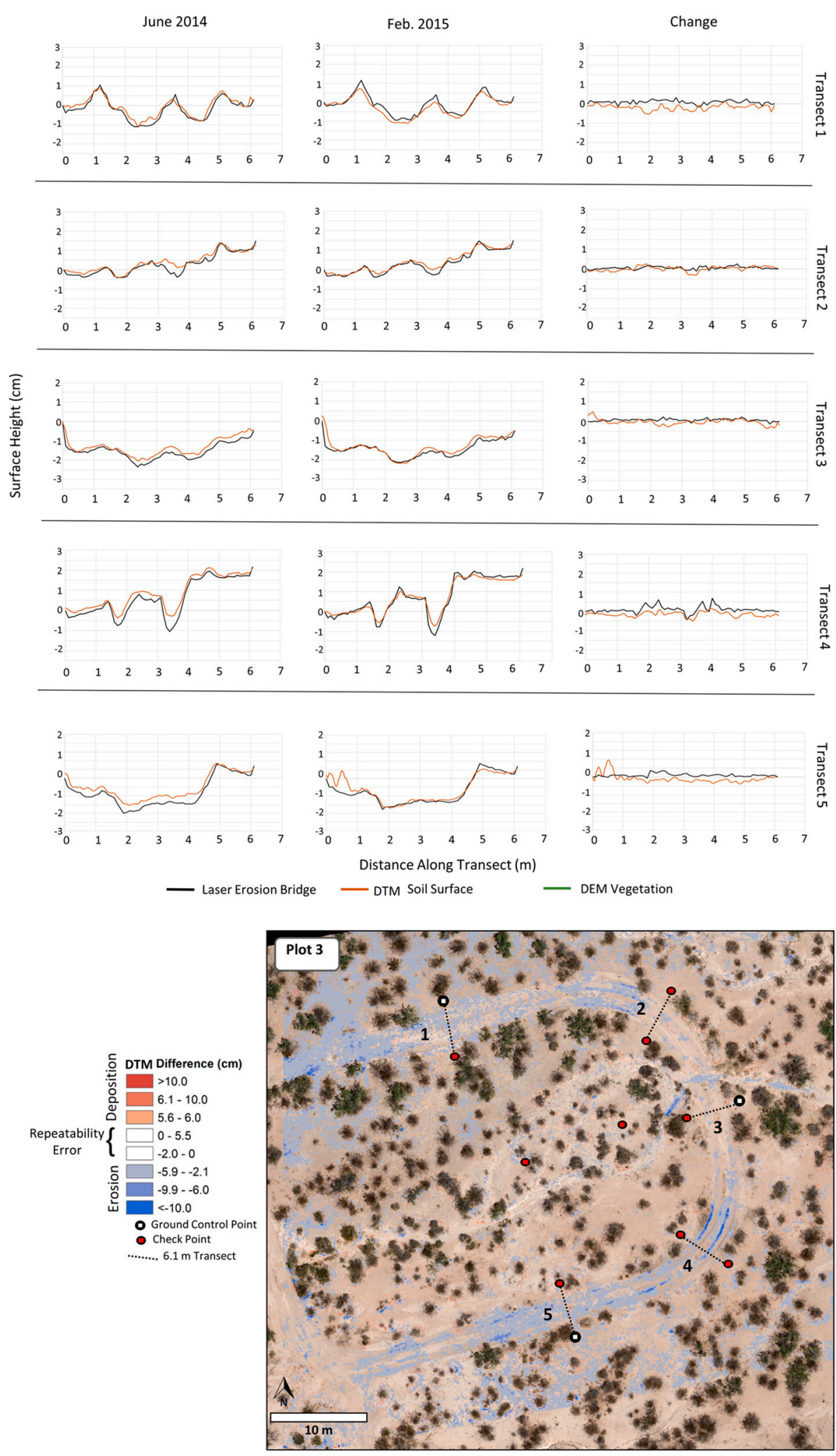

Figure A3. Plot 3 DTM differences and topographic profiles. 

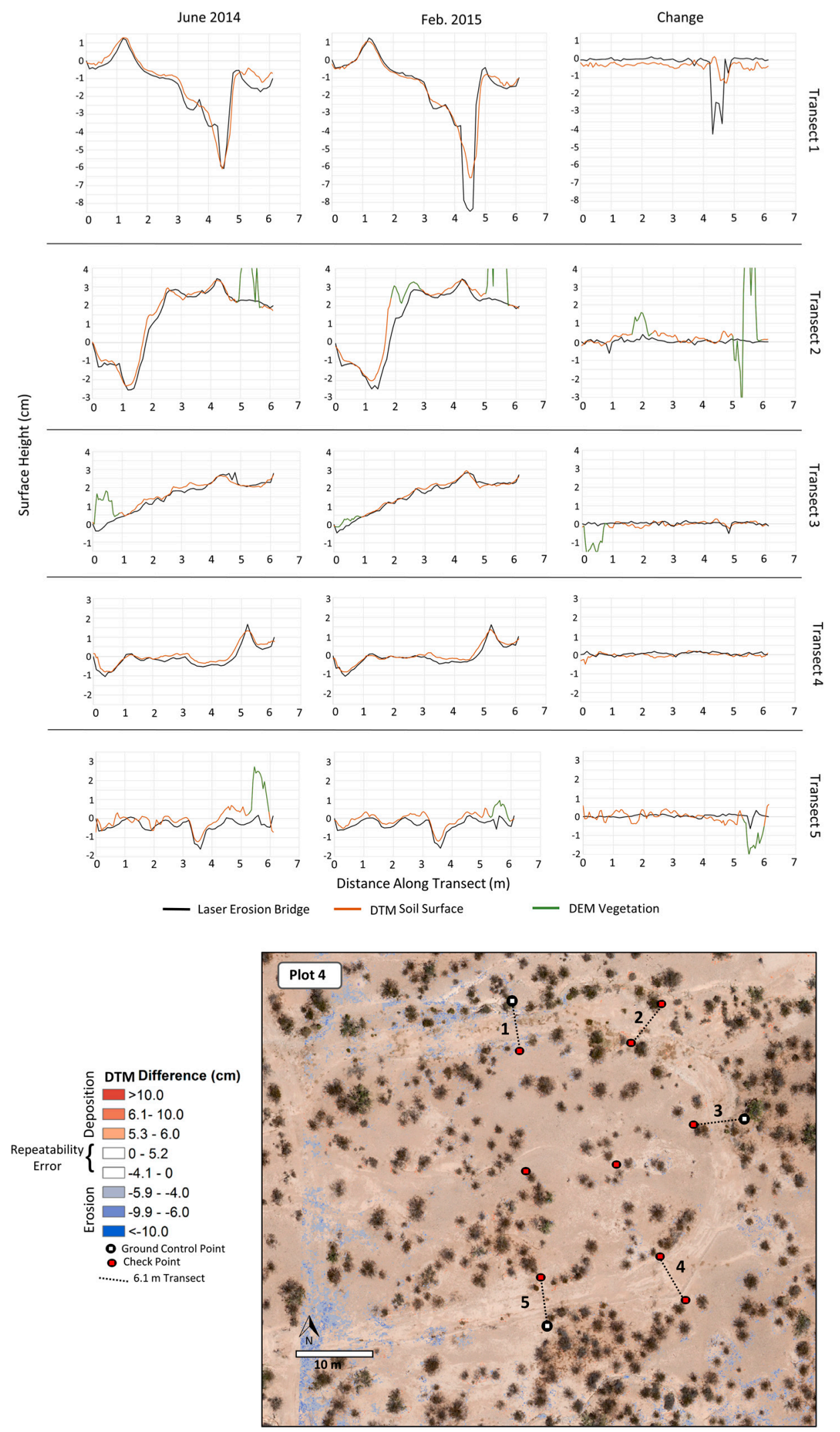

Figure A4. Plot 4 DTM differences and topographic profiles. 

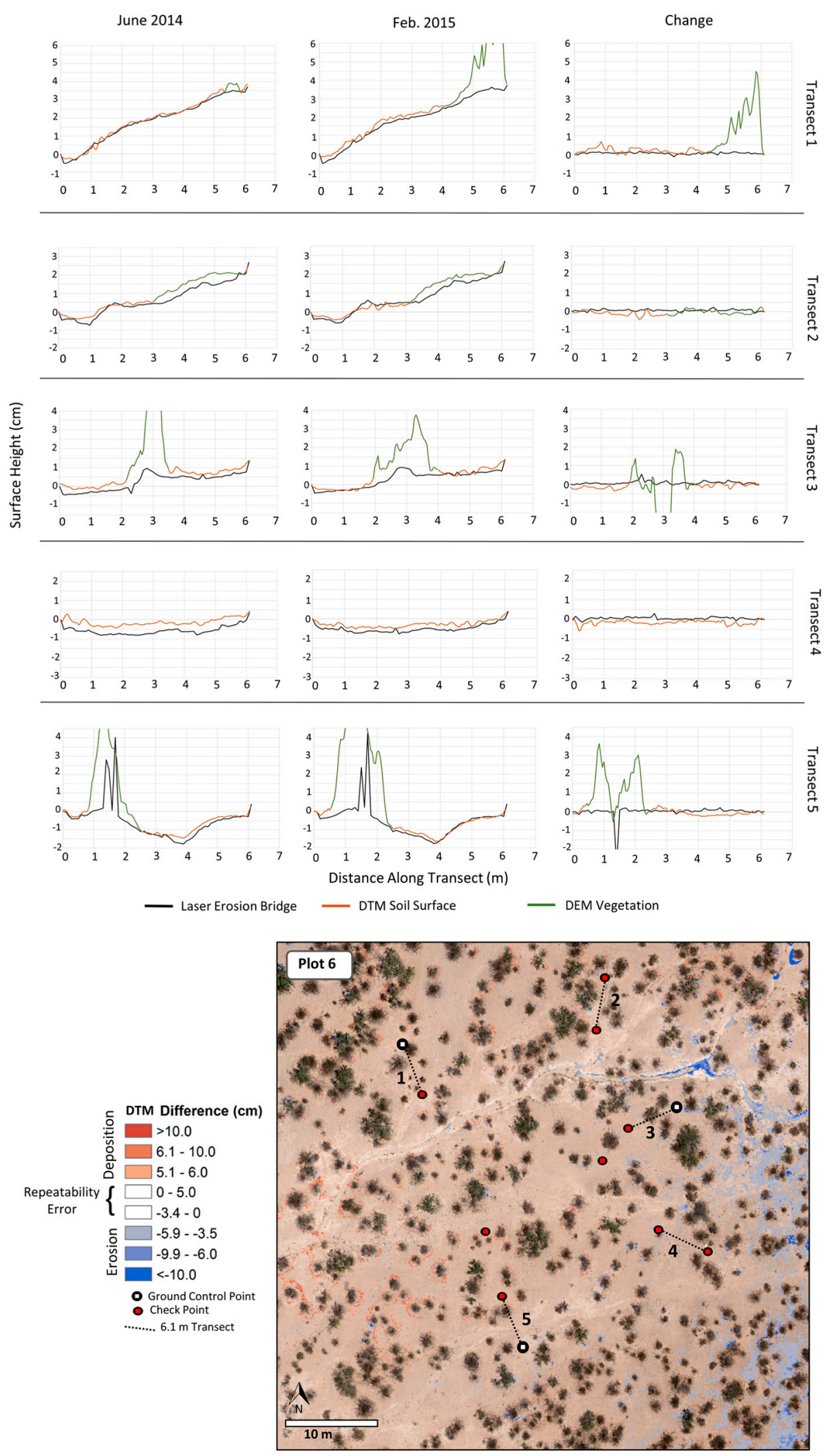

Figure A5. Plot 6 DTM differences and topographic profiles. 


\section{References}

1. Martinez-Casasnovas, J.A.; Anton-Fernandez, C.; Ramos, M.C. Sediment production in large gullies of the Mediterranean area (NE Spain) from high-resolution digital elevation models and geographical information systems analysis. Earth Surf. Process. Landf. 2003, 28, 443-456. [CrossRef]

2. Marzolff, I.; Poesen, J. The potential of 3D gully monitoring with GIS using high-resolution aerial photography and a digital photogrammetry system. Geomorphology 2009, 111, 48-60. [CrossRef]

3. D'Oleire-Oltmanns, S.; Marzolff, I.; Peter, K.; Ries, J. Unmanned Aerial Vehicle (Uav) for monitoring soil erosion in morocco. Remote Sens. 2012, 4, 3390-3416. [CrossRef]

4. Eltner, A.; Baumgart, P.; Maas, H.-G.; Faust, D. Multi-temporal UAV data for automatic measurement of rill and interrill erosion on loess soil. Earth Surf. Process. Landf. 2014, 40, 741-755. [CrossRef]

5. Gillan, J.K.; Karl, J.W.; Barger, N.N.; Elaksher, A.; Duniway, M.C. Spatially explicit rangeland erosion monitoring using high-resolution digital aerial imagery. Rangel. Ecol. Manag. 2016, 69, 95-107. [CrossRef]

6. Goodrich, D.C.; Guertin, D.P.; Burns, I.S.; Nearing, M.A.; Stone, J.J.; Wei, H.; Heilman, P.; Hernandez, M.; Spaeth, K.; Pierson, F; et al. AGWA: The automated geospatial watershed assessment tool to inform rangeland management. Rangelands 2011, 33, 41-47. [CrossRef]

7. Al-Hamdan, O.Z.; Hernandez, M.; Pierson, F.B.; Nearing, M.A.; Williams, C.J.; Stone, J.J.; Boll, J.; Weltz, M.A. Rangeland hydrology and erosion model (RHEM) enhancements for applications on disturbed rangelands. Hydrol. Process. 2014, 29, 445-457. [CrossRef]

8. Vivoni, E.; Rango, A.; Anderson, C. Ecohydrology with unmanned aerial vehicles. Ecosphere 2014, 5, 1-14. [CrossRef]

9. Lassueur, T.; Joost, S.; Randin, C.F. Very high resolution digital elevation models: Do they improve models of plant species distribution? Ecol. Model. 2006, 198, 139-153. [CrossRef]

10. Templeton, R.C.; Vivoni, E.R.; Méndez-Barroso, L.A.; Pierini, N.A.; Anderson, C.A.; Rango, A.; Laliberte, A.S.; Scott, R.L. High-resolution characterization of a semiarid watershed: Implications on evapotranspiration estimates. J. Hydrol. 2014, 509, 306-319. [CrossRef]

11. Niethammer, U.; Rothmund, S.; James, M.R.; Travelletti, J.; Joswig, M. UAV-based remote sensing of landslides. Int. Arch. Photogramm. Remote Sens. Spat. Inf. Sci. 2010, 38, 496-501.

12. Harwin, S.; Lucieer, A. Assessing the accuracy of georeferenced point clouds produced via multi-view stereopsis from Unmanned Aerial Vehicle (UAV) imagery. Remote Sens. 2012, 4, 1573-1599. [CrossRef]

13. Lucieer, A.; Jong, S.M.D.; Turner, D. Mapping landslide displacements using Structure from Motion (SfM) and image correlation of multi-temporal UAV photography. Prog. Phys. Geogr. 2013, 38, 97-116. [CrossRef]

14. Rosnell, T.; Honkavaara, E. Point cloud generation from aerial image data acquired by a quadrocopter type micro unmanned aerial vehicle and a digital still camera. Sensors 2012, 12, 453-480. [CrossRef] [PubMed]

15. Pajares, G. Overview and current status of remote sensing applications based on Unmanned Aerial Vehicles (UAVs). Photogramm. Eng. Remote Sens. 2015, 81, 281-330. [CrossRef]

16. Snavely, N.; Seitz, S.M.; Szeliski, R. Modeling the world from Internet photo collections. Int. J. Comput. Vis. 2008, 80, 189-210. [CrossRef]

17. Gonçalves, J.A.; Henriques, R. UAV photogrammetry for topographic monitoring of coastal areas. ISPRS J. Photogramm. Remote Sens. 2015, 104, 101-111. [CrossRef]

18. Fonstad, M.A.; Dietrich, J.T.; Courville, B.C.; Jensen, J.L.; Carbonneau, P.E. Topographic structure from motion: A new development in photogrammetric measurement. Earth Surf. Process. Landf. 2013, 38, 421-430. [CrossRef]

19. Ai, M.; Hu, Q.; Li, J.; Wang, M.; Yuan, H.; Wang, S. A robust photogrammetric processing method of low-altitude UAV images. Remote Sens. 2015, 7, 2302-2333. [CrossRef]

20. Westoby, M.J.; Brasington, J.; Glasser, N.F.; Hambrey, M.J.; Reynolds, J.M. "Structure-from-Motion" photogrammetry: A low-cost, effective tool for geoscience applications. Geomorphology 2012, 179, 300-314. [CrossRef]

21. Anderson, K.; Gaston, K.J. Lightweight unmanned aerial vehicles will revolutionize spatial ecology. Front. Ecol. Environ. 2013, 11, 138-146. [CrossRef]

22. Shakesby, R.A. The soil erosion bridge: A device for micro-profiling soil surfaces. Earth Surf. Process. Landf. 1993, 18, 823-827. [CrossRef] 
23. Fanning, P. Long-term contemporary erosion rates in an arid rangelands environment in western New South Wales, Australia. J. Arid Environ. 1994, 28, 173-187. [CrossRef]

24. Sirvent, J.; Desir, G.; Gutierrez, M.; Sancho, C.; Benito, G. Erosion rates in badland areas recorded by collectors, erosion pins and profilometer techniques (Ebro Basin, NE-Spain). Geomorphology 1997, 18, 61-75. [CrossRef]

25. Martínez-Casasnovas, J.A.; Ramos, M.C.; Ribes-Dasi, M. Soil erosion caused by extreme rainfall events: mapping and quantification in agricultural plots from very detailed digital elevation models. Geoderma 2002, 105, 125-140. [CrossRef]

26. Wheaton, J.M.; Brasington, J.; Darby, S.E.; Sear, D.A. Accounting for uncertainty in DEMs from repeat topographic surveys: Improved sediment budgets. Earth Surf. Process. Landf. 2009, 156, 136-156. [CrossRef]

27. Wallace, L.; Lucieer, A.; Malenovský, Z.; Turner, D.; Vopěnka, P. Assessment of forest structure using two UAV techniques: A comparison of airborne laser scanning and structure from motion (SfM) point clouds. Forests 2016, 7, 62. [CrossRef]

28. Neugirg, F.; Stark, M.; Kaiser, A.; Vlacilova, M.; Della Seta, M.; Vergari, F.; Schmidt, J.; Becht, M.; Haas, F. Erosion processes in calanchi in the Upper Orcia Valley, Southern Tuscany, Italy based on multitemporal high-resolution terrestrial LiDAR and UAV surveys. Geomorphology 2016, 269, 8-22. [CrossRef]

29. Lucieer, A.; Turner, D.; King, D.H.; Robinson, S.A. Using an Unmanned Aerial Vehicle (UAV) to capture micro-topography of antarctic moss beds using an Unmanned Aerial Vehicle (UAV) to capture micro-topography. Int. J. Appl. Earth Obs. Geoinf. 2014, 27, 53-62. [CrossRef]

30. Clapuyt, F.; Vanacker, V.; Van Oost, K. Reproducibility of uav-based earth topography reconstructions based on structure-from-motion algorithms. Geomorphology 2015, 260, 4-15. [CrossRef]

31. Stöcker, C.; Eltner, A.; Karrasch, P. Measuring gullies by synergetic application of UAV and close range photogrammetry-A case study from Andalusia, Spain. Catena 2015, 132, 1-11. [CrossRef]

32. Eltner, A.; Schneider, D. Analysis of different methods for $3 \mathrm{D}$ reconstruction of natural surfaces from parallel-axes UAV images. Photogramm. Rec. 2015, 30, 279-299. [CrossRef]

33. Milan, D.J.; Heritage, G.L.; Large, A.R.G.; Fuller, I.C. Filtering spatial error from DEMs: Implications for morphological change estimation. Geomorphology 2011, 125, 160-171. [CrossRef]

34. Nash, M.S.; Jackson, E.; Whitford, W.G. Soil microtopography on grazing gradients in Chihuahuan desert grasslands. J. Arid Environ. 2003, 55, 181-192. [CrossRef]

35. White, C.S.; Loftin, S.R. Response of 2 semiarid grasslands to cool-season pre-scribed fire. J. Range Manag. 2000, 53, 52-61. [CrossRef]

36. White, C.S.; Pendleton, R.L.; Pendleton, B.K. Response of two semiarid grasslands to a second fire application. Rangel. Ecol. Manag. 2006, 59, 98-106. [CrossRef]

37. Sankey, J.B.; Glenn, N.F.; Germino, M.J.; Gironella, A.I.N.; Thackray, G.D. Relationships of aeolian erosion and deposition with LiDAR-derived landscape surface roughness following wildfire. Geomorphology 2010, 119, 135-145. [CrossRef]

38. Shakesby, R.A.; Coelho, C.O.A.; Ferreira, A.J.D.; Walsh, R.P.D. Ground-level changes after wildfire and ploughing in eucalyptus and pine forests, Portugal: Implications for soil microtopographical development and soil longevity. Land Degrad. Dev. 2002, 13, 111-127. [CrossRef]

39. Van De, N.; Douglas, I.; Mcmorrow, J.; Lindley, S.; Thuy Binh, D.K.N.; Van, T.T.; Thanh, L.H.; Tho, N. Erosion and nutrient loss on sloping land under intense cultivation in Southern Vietnam. Geogr. Res. 2008, 46, 4-16. [CrossRef]

40. Eagleston, H.; Rubin, C. Non-motorized winter recreation impacts to snowmelt erosion, tronsen basin, eastern cascades, Washington. Environ. Manag. 2013, 51, 167-181. [CrossRef] [PubMed]

41. Okayasu, T.; Muto, M.; Jamsran, U.; Takeuchi, K. Spatially heterogeneous impacts on rangeland after social system change in Mongolia. Land Degrad. Dev. 2007, 18, 555-566. [CrossRef]

42. Brooks, M.L.; Lair, B. Ecological Effects of Vehicular Routes in a Desert Ecosystem; Western Ecological Research Center: Las Vegas, NV, USA, 2005.

43. Watts, R.D.; Compton, R.W.; Mccammon, J.H.; Rich, C.L.; Wright, M.S.; Owens, T.; Ouren, D.S. Roadless space of the conterminous United States. Science 2007, 316, 736-738. [CrossRef] [PubMed]

44. Duniway, M.C.; Herrick, J.E. Disentangling road network impacts: The need for a holistic approach. J. Soil Water Conserv. 2011, 66, 31A-36A. [CrossRef] 
45. Laflen, J.M.; Forest, S. WEPP-Predicting water erosion using a process-based model. J. Soil Water Conserv. 1997, 52, 96-102.

46. Grismer, M.E. Soil restoration and erosion control: Quantitative assessment and direction. Trans. ASABE 2007, 50, 1619-1626. [CrossRef]

47. Duniway, M.C.; Herrick, J.E.; Pyke, D.A.; Toledo, P.D. Assessing transportation infrastructure impacts on rangelands: Test of a Standard rangeland assessment protocol. Rangel. Ecol. Manag. 2010, 63, 524-536. [CrossRef]

48. Duniway, M.C.; Herrick, J.E. Assessing impacts of roads: Application of a Standard assessment protocol. Rangel. Ecol. Manag. 2013, 66, 364-375. [CrossRef]

49. Herrick, J.E.; Van Zee, J.W.; Harvstad, K.M.; Burkett, L.M.; Whitford, W.G. Monitoring Manual for Grassland, Shrubland, and Savanna Ecosystems: Volume II; Jornada Experimental Range: Las Cruces, NM, USA, 2009.

50. Turner, D.; Lucieer, A.; Wallace, L. Direct georeferencing of ultrahigh-resolution UAV imagery. IEEE Trans. Geosci. Remote Sens. 2014, 52, 2738-2745. [CrossRef]

51. Smith, M.W.; Carrivick, J.L.; Hooke, J.; Kirkby, M.J. Reconstructing flash flood magnitudes using "Structure-from-Motion": A rapid assessment tool. J. Hydrol. 2014, 519, 1914-1927. [CrossRef]

52. Javernick, L.; Brasington, J.; Caruso, B. Modeling the topography of shallow braided rivers using Structure-from-Motion photogrammetry. Geomorphology 2014, 213, 166-182. [CrossRef]

53. Kraus, K. Photogrammetry: Geometry from Images and Laser Scans; De Gruyter: Berlin, Germany, 2007.

54. McGlone, J.C. Manual of Photogrammetry; American Society for Photogrammetry and Remote Sensing: Bethesda, MD, USA, 2013.

55. Eltner, A.; Kaiser, A.; Castillo, C.; Rock, G.; Neugirg, F.; Abellan, A. Image-based surface reconstruction in geomorphometry-Merits, limits and developments of a promising tool for geoscientists. Earth Surf. Dyn. Discuss. 2016, 3, 1445-1508. [CrossRef]

56. Turner, D.; Lucieer, A.; Watson, C. An automated technique for generating georectified mosaics from ultra-high resolution Unmanned Aerial Vehicle (UAV) imagery, based on structure from motion (SfM) point clouds. Remote Sens. 2012, 4, 1392-1410. [CrossRef]

57. Long, N.; Millescamps, B.; Pouget, F.; Dumon, A.; Lachaussée, N.; Bertin, X. Accuracy assessment of coastal topography derived from UAV images. ISPRS Int. Arch. Photogramm. Remote Sens. Spat. Inf. Sci. 2016, XLI-B1, 1127-1134. [CrossRef]

58. Tonkin, T.N.; Midgley, N.G. Ground-control networks for image based surface reconstruction: An investigation of optimum survey designs using UAV derived imagery and structure-from-motion photogrammetry. Remote Sens. 2016, 8, 16-19. [CrossRef]

59. James, M.R.; Robson, S.; D'Oleire-Oltmanns, S.; Niethammer, U. Optimising UAV topographic surveys processed with structure-from-motion: Ground control quality, quantity and bundle adjustment. Geomorphology 2017, 280, 51-66. [CrossRef]

60. Baykal, O.; Tari, E.; Coşkun, M.Z.; Erden, T. Accuracy of point layout with polar coordinates. J. Surv. Eng. 2005, 131, 87-93. [CrossRef]

61. Franklin, K.D.; Meyer, T.H. Centering error for range poles. Surv. Land Inf. Sci. 2016, 75, 77-84.

62. Leica Geosystems. Available online: http://pdf.directindustry.com/pdf/leica-geosystems/leica-flexlinets02plus/14324-254223.html (accessed on 24 April 2017).

63. Lowe, D.G. Distinctive image features from scale invariant keypoints. Int. J. Comput. Vis. 2004, 60, 91-110. [CrossRef]

64. Harwin, S.; Lucieer, A.; Osborn, J. The impact of the calibration method on the accuracy of point clouds derived using unmanned aerial vehicle multi-view stereopsis. Remote Sens. 2015, 7, 11933-11953. [CrossRef]

65. Agisoft. Available online: http://www.agisoft.com/pdf/photoscan-pro_1_1_en.pdf (accessed on 24 April 2017).

66. Smith, M.W.; Carrivick, J.L.; Quincey, D.J. Structure from motion photogrammetry in physical geography. Prog. Phys. Geogr. 2015, 40, 247-275. [CrossRef]

67. Cunliffe, A.M.; Brazier, R.E.; Anderson, K. Ultra-fine grain landscape-scale quantification of dryland vegetation structure with drone-acquired structure-from-motion photogrammetry. Remote Sens. Environ. 2016, 183, 129-143. [CrossRef]

68. jkarl/Photogrammetry. Available online: https://github.com/jkarl/photogrammetry (accessed on 1 April 2017). 
69. Lane, S.N.; Westaway, R.M.; Murray Hicks, D. Estimation of erosion and deposition volumes in a large, gravel-bed, braided river using synoptic remote sensing. Earth Surf. Process. Landf. 2003, 28, $249-271$. [CrossRef]

70. Brasington, J.; Langham, J.; Rumsby, B. Methodological sensitivity of morphometric estimates of coarse fluvial sediment transport. Geomorphology 2003, 53, 299-316. [CrossRef]

71. Derose, R.C.; Gomez, B.; Marden, M.; Trustrum, N.A. Gully erosion in Mangatu Forest, New Zealand, estimated from digital elevation models. Earth Surf. Process. Landf. 1998, 23, 1045-1053. [CrossRef]

72. Gessesse, G.D.; Fuchs, H.; Mansberger, R.; Klik, A.; Rieke-Zapp, D.H. Assessment of ersosion, deposition and rill development on irregular soil surfaces using close range digital photogrammetry. Photogramm. Rec. 2010, 25, 299-318. [CrossRef]

73. Glendell, M.; McShane, G.; Farrow, L.; James, M.R.; Quinton, J.; Anderson, K.; Evans, M.; Benaud, P.; Rawlins, B.; Morgan, D.; et al. Testing the utility of structure from motion photogrammetry reconstructions using small unmanned aerial vehicles and ground photography to estimate the extent of upland soil erosion. Earth Surf. Process. Landf. 2017. [CrossRef]

74. Mudge, J.F.; Baker, L.F.; Edge, C.B.; Houlahan, J.E. Setting an optimal $\alpha$ that minimizes errors in null hypothesis significance tests. PLoS ONE 2012, 7, e32734. [CrossRef] [PubMed]

75. James, M.R.; Robson, S. Mitigating systematic error in topographic models derived from UAV and ground-based image networks. Earth Surf. Process. Landf. 2014, 39, 1413-1420. [CrossRef]

76. Jaud, M.; Passot, S.; Le Bivic, R.; Delacourt, C.; Grandjean, P.; Le Dantec, N. Assessing the accuracy of high resolution digital surface models computed by PhotoScan ${ }^{\circledR}$ and MicMac ${ }^{\circledR}$ in sub-optimal survey conditions. Remote Sens. 2016, 8, 465. [CrossRef]

77. Jensen, J.L.R.; Mathews, A.J. Assessment of image-based point cloud products to generate a bare earth surface and estimate canopy heights in a woodland ecosystem. Remote Sens. 2016, 8, 50. [CrossRef]

78. Rehak, M.; Mabillard, R.; Skaloud, J. A micro-UAV with the capability of direct georeferencing. Int. Arch. Photogramm. Remote Sens. Spat. Inf. Sci. 2013, XL-1/W2, 317-323. [CrossRef]

79. Hugenholtz, C.; Brown, O.; Walker, J.; Barchyn, T.; Nesbit, P.; Kucharczyk, M.; Myshak, S. Spatial accuracy of UAV-derived orthoimagery and topography: Comparing photogrammetric models processed with direct geo-referencing and ground control points. Geomatica 2016, 70, 21-30. [CrossRef]

80. Carbonneau, P.E.; Dietrich, J.T. Cost-effective non-metric photogrammetry from consumer-grade sUAS: Implications for direct georeferencing of structure from motion photogrammetry. Earth Surf. Process. Landf. 2016, 42, 473-486. [CrossRef]

81. Goff, S.A.; Vaughn, M.; McKay, S.; Lyons, E.; Stapleton, A.E.; Gessler, D.; Matasci, N.; Wang, L.; Hanlon, M.; Lenards, A.; et al. The iPlant collaborative: Cyberinfrastructure for plant biology. Front. Plant Sci. 2011, 2, 34. [CrossRef] [PubMed]

(c) 2017 by the authors. Licensee MDPI, Basel, Switzerland. This article is an open access article distributed under the terms and conditions of the Creative Commons Attribution (CC BY) license (http://creativecommons.org/licenses/by/4.0/). 